\title{
The Timing and Duration of the Delamerian Orogeny: Correlation with the Ross Orogen and Implications for Gondwana Assembly
}

\author{
John Foden, Marlina A. Elburg, ${ }^{1}$ Jon Dougherty-Page, and Andrew Burtt ${ }^{2}$ \\ Geology and Geophysics, University of Adelaide, Adelaide, South Australia 5005, Australia \\ (e-mail: john.foden@adelaide.edu.au)
}

\begin{abstract}
A B S T R A C T
The Antarctic Ross and the Australian Delamerian orogenies are the consequence of stress transfer to the outboard trailing edge of the newly assembled Gondwana supercontinent. This tectonic reorganization occurred in the Early to Middle Cambrian on completion of Pan-African deformation and subduction along the sutures between eastern and western Gondwanan continental fragments. Before this, Neoproterozoic to Early Cambrian rocks in eastern Australia were formed in a passive margin and record dispersion of Rodinia with consequent opening of the protoPacific. Our new U-Pb and Rb-Sr geochronology shows that in the South Australian (Adelaide Fold Belt) domain of the Delamerian Orogen, contractional orogenesis commenced at $514 \pm 3 \mathrm{Ma}$ and persisted for $\sim 24 \mathrm{~m}$.yr. until $490 \pm 3 \mathrm{Ma}$, terminated by rapid uplift, cooling, and extension in association with posttectonic magmatism. Integration of new and published U-Pb and ${ }^{40} \mathrm{Ar}^{39}{ }^{39} \mathrm{Ar}$ geochronology from the entire Ross-Delamerian belt shows that although both the Delamerian and Ross have a synchronous late magmatic and terminal cooling history, the Ross commenced its convergent orogenic history at $\sim 540 \mathrm{Ma}$. This was $25 \mathrm{~m}$.yr. before Delamerian deformation began. During the Early Cambrian, eastern Australia was still in a state of extension (or transtension), with opening of the Kanmantoo Basin and associated anorogenic, largely mafic magmatism. This basin received sediment from the already exposed Ross Orogen to the south. The simultaneous first occurrence of strain fabrics and subduction-related magmatism (including boninite, granite, and andesite lavas) at 514 Ma in New Zealand, Victoria, South Australia, New South Wales, and Tasmania implies that the Delamerian Orogeny was driven by ridge-push forces transmitted on the initiation of westward-dipping subduction. Subsequent eastward slab rollback at 490 Ma may have occurred when the new slab had reached the transition zone at $650-\mathrm{km}$ depth, resulting in upper plate extension and anorogenic Basin and Range-style magmatism in South Australia and Tasmania (Mount Read belt). The delayed onset of subduction in the Australian sector of the margin implies that westward motion of the Australian portion of eastern Gondwana continued to be accommodated during the late Early Cambrian by subduction or deformation along either the Mozambique Suture or at the northern end of the South Prince Charles Mountains-Prydz Bay suture.
\end{abstract}

Online enhancements: appendix tables.

\section{Introduction}

In order to test correlations and provide constraints on physical models of orogenesis, it is important to determine a precise chronology of the thermal, magmatic, and structural events that define an orogenic belt. In this article, we present new geochronological results from several critical sites in the southern part of the Adelaide Fold Belt, part of the 2005.

Manuscript received January 27, 2005; accepted October 24, ${ }^{1}$ Pres

Present address: Department of Geology and Soil Sciences, Ghent University, Krijgslaan 281 S8, 9000 Ghent, Belgium.

${ }^{2}$ Office of Minerals and Energy Resources, Department of Primary Industries, Adelaide, South Australia, Australia.
Cambro-Ordovician Delamerian Orogen of southeastern Australia (fig. 1). These new data are integrated with existing age dates from the Delamerian and Ross orogens to provide better constraints on the tectonic development of this tectonically active edge of the Gondwana supercontinent.

Regional Setting of the Delamerian Orogen. The Delamerian Orogen encompasses Precambrian and Early Cambrian rock sequences in eastern Australia that experienced Cambrian deformation and metamorphism. It separates the Australian Precambrian cratons from the younger Paleozoic to 

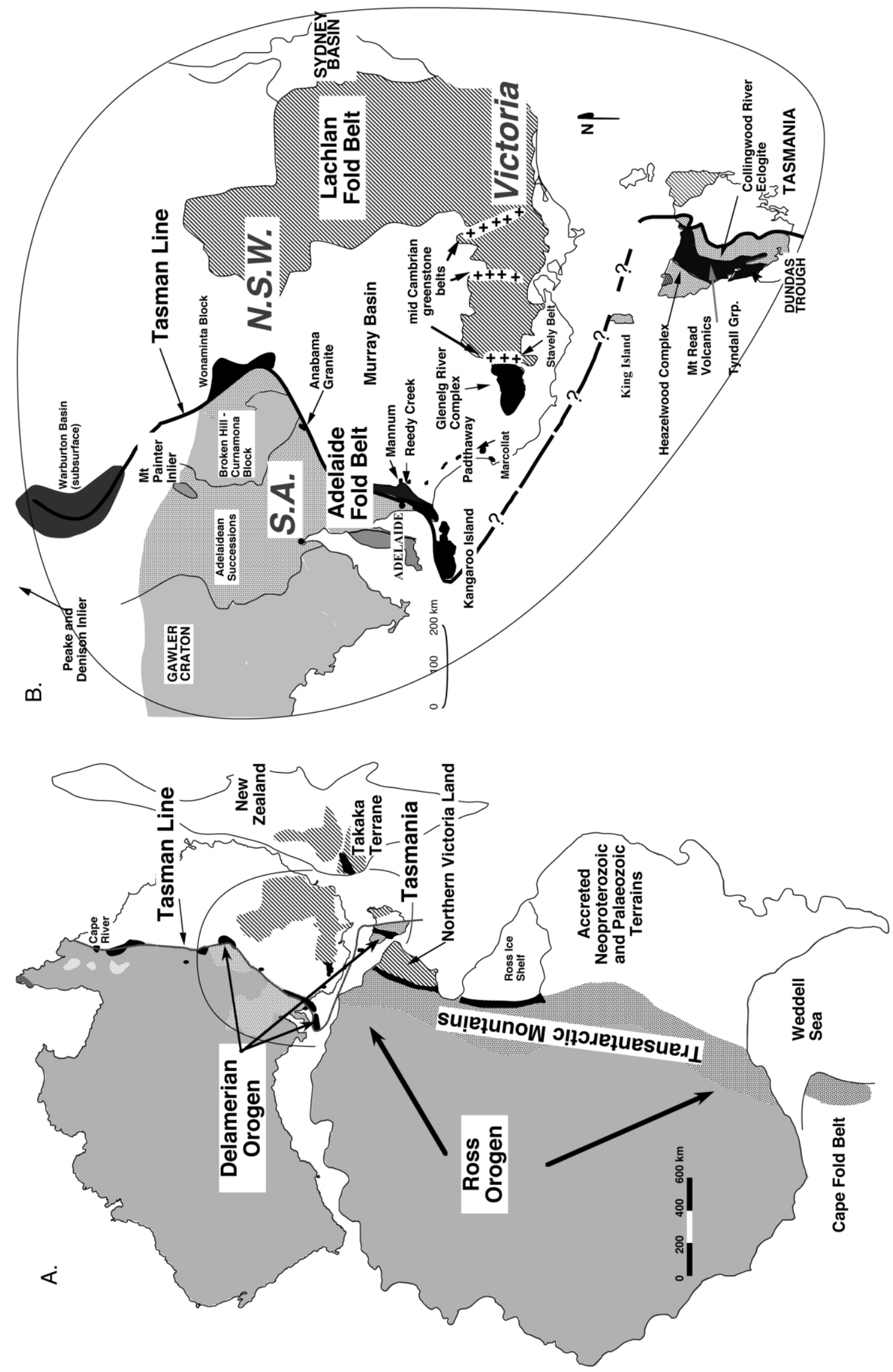
Mesozoic orogenic belts of eastern Australia (fig. 1). It includes the South Australian Adelaide Fold Belt, the Glenelg Complex in western Victoria, the Wonaminta Block in western New South Wales, and the Precambrian and Cambrian sequences in Tasmania (Coney et al. 1990). The Adelaide Fold Belt stretches $1100 \mathrm{~km}$ from the Peake and Denison inliers in the far north of South Australia to the western tip of Kangaroo Island in the south. South from Australia, the Delamerian Orogen extends into Antarctica, where it is known as the Ross Orogen (Stump 1995; Goodge 1997), underlying the Transantarctic Mountains from northern Victoria Land to the Weddell Sea (Dalziel 1991) and then into southern Africa to form the Cape Fold Belt (fig. 1).

In South Australia, Victoria, western New South Wales and Tasmania, the Delamerian Orogen is composed mainly of Late Neoproterozoic (Adelaidean) and Early Cambrian sedimentary rocks that were deposited in a passive margin setting. These host anorogenic rift-related mafic igneous suites (Foden et al. 2002a; Meffre et al. 2004). In South Australia (and in the Glenelg region of Victoria), Early Cambrian sedimentary sequences comprise the basal Normanville and succeeding Kanmantoo Groups, deposited in the Stansbury Basin (Milnes et al. 1977; Preiss 1987; Haines and Flöttmann 1998; Haines et al. 2001). These sequences host Late Neoproterozoic to Early Ordovician mafic igneous suites (Foden et al. 2002a) and Middle Cambrian to Early Ordovician syn- to posttectonic granite suites and felsic volcanics whose ages range from 514 to $475 \mathrm{Ma}$ (Foden et al. 2002b). In South Australia, the fold belt also incorporates Paleo- to Mesoproterozoic basement inliers, including that at Mount Painter (Paul et al. 1999; Elburg et al. 2003) in the north (fig. 1B). In Tasmania, the preDelamerian passive margin sequences are overlain by synorogenic Middle to Late Cambrian sedimentary sequences associated with intermediate to felsic volcanics (Mount Read volcanics; Crawford and
Berry 1992; Turner et al. 1998). Although mainly obscured by younger sequences of the CooperEromanga and Bowen basins, the Delamerian belt can be traced northward to the Cape River area in northern Queensland (fig. 1).

The Delamerian is a compressional orogenic zone with westward-verging folds and thrust faults (Offler and Fleming 1968; Fleming and White 1984; Mancktelow 1990; Jenkins and Sandiford 1992; Flöttmann et al. 1994). Earliest deformation (D1) was associated with west-verging thrusts and resulted in low-angle S1 fabrics (Flöttmann et al. 1994). Up to two subsequent phases of tight to open, upright folds developed during D2 and D3 deformations, yielding S2 and S3 fabrics (Offler and Fleming 1968; Mancktelow 1990). Metamorphism developed at low $P$ and high $T$ conditions (Offler and Fleming 1968; Dymoke and Sandiford 1992; Sandiford et al. 1992; Alias et al. 2002) with large variation from chlorite to sillimanite grade. Highest grades are confined to restricted zones that are also the site of syntectonic granite intrusion and structural complexity. Deformation and metamorphism occurred from the early Middle Cambrian (514 $\pm 4 \mathrm{Ma}$; Foden et al. 1999) to the latest Cambrian $(\sim 490 \mathrm{Ma})$. This activity is concurrent with subduction-related arc volcanism $>500 \mathrm{~km}$ to the east in the Takaka Terrane in New Zealand (Münker and Cooper 1995; Münker and Crawford 2000).

Regional Geology and Geochronology. Knowledge of the geochronological framework of the Paleozoic events in the Adelaide Fold Belt has arisen in a piecemeal fashion. Compston et al. (1966) and Milnes et al. (1977) provided much of the early data and interpretation, based mainly on their Rb-Sr and K-Ar analyses. Drexel and Preiss (1995) summarized these and most of the other more recent data sources. Because of the complex thermal and structural history of the belt and its short absolute duration, many of these earlier data are insufficiently precise to resolve tectonic events. Because the iso-

Figure 1. A, Pre-Cretaceous configuration of the Delamerian and Ross orogens in East Gondwana. Gray shading $=$ cratonic regions mainly underlain by Paleoproterozoic and Archaean basement. Stippled pattern $=$ Late Precambrian sequences deformed and metamorphosed in the Early to Middle Cambrian. Black = Early Cambrian rocks deformed in the Middle to Late Cambrian. Diagonal striping = post-Middle Cambrian Paleozoic outcrops not deformed until after the Cambrian. B, Southeastern Australia. Gray shading = pre-Neoproterozoic basement. Stippled pattern $=$ Neoproterozoic sediment-dominant, passive margin sequences deformed in the Delamerian. Dark shaded areas $=$ Cambrian sequences deformed in the Delamerian Orogeny. Diagonal striping = Ordovician to Carboniferous sequences deformed in the Paleozoic. Murray Basin = Mesozoic and younger undeformed marine and nonmarine sedimentary cover over Cambrian basement. Sydney Basin $=$ Permian and Triassic marine and nonmarine sedimentary cover. The Tasman Line is the eastern limit of the outcrop of known Precambrian rocks. 
tope systems used in these earlier studies have closure at temperatures below which the interior parts of the orogen cooled only during terminal orogenic stages, they date only final cooling and erosion. A U-Pb SHRIMP date $(526 \pm 4 \mathrm{Ma})$ by Cooper et al. (1992) on zircon from a tuff layer in the basal part of the pre-Delamerian Lower Cambrian strata (the Normanville Group) has provided a critical piece of robust evidence, placing a maximum age limit on the entire Delamerian cycle of Cambrian sedimentation and orogenic basin inversion. Based on new standards, this date has recently been reassessed and now returns an age of $522 \pm 2 \mathrm{Ma}$ (Jenkins et al. 2002). ${ }^{40} \mathrm{Ar}^{39} \mathrm{Ar}$ data (hornblende and micas) were collected and interpreted by Turner et al. (1996), and U-Pb SHRIMP and ${ }^{207} \mathrm{~Pb}-{ }^{206} \mathrm{~Pb}$ zircon evaporation results have been presented by Foden et al. (1999). In addition, recent SHRIMP U-Pb ion probe analyses of zircon were carried out to support South Australian Geological Survey (PIRSA) mapping (e.g., Fanning 1990). The present understanding of the temporal framework of events in the belt was summarized in several recent studies (Haines and Flöttmann 1998; Foden et al. 1999, 2002a, 2002b).

The objective of this article is to establish the precise timing of events that constitute the Delamerian Orogeny and to use this information to demonstrate its relationship to the Ross Orogeny in Antarctica. We utilize data from the literature and new $\mathrm{U}-\mathrm{Pb}$ and $\mathrm{Pb}-\mathrm{Pb}$ isotopic measurements on samples from critical sites in the Adelaide Fold Belt where unequivocal geological relations exist (tables 1, 2; figs. 1, 2). Sites at Reedy Creek, Monarto, and on the south coast of Kangaroo Island each have syn- and posttectonic igneous suites with relationships that permit dating of D2-D3 deformation stages. Granite samples from Mannum (fig. 2) and on the Padthaway Ridge in the southeast of South Australia constrain the age of posttectonic magmatic activity. The Bungadillina monzonite from the Peake and Denison Ranges (Morrison and Foden 1990) in the far north of the belt was also dated because prior work on this suite yielded ages that (falsely) indicated significantly earlier commencement of orogenic activity in the north compared with the southern Adelaide Fold Belt.

Analytical Techniques. In this article, the new geochronological results we report are either ${ }^{207} \mathrm{~Pb}$ ${ }^{206} \mathrm{~Pb}$ evaporation data from zircons or U-Pb analyses of zircons, titanites, and monazite. Samples for U-Pb geochronology were crushed in a stainless steel jaw crusher after removal of weathered rims. Crushing, sieving, Wilfley table separation, and then heavy liquid and Franz magnetic separation obtained nearly pure mineral separates. The final separates were handpicked. The bulk rock samples from which the minerals were separated were analyzed by $\mathrm{x}$-ray fluorescence (XRF) for major and trace elements at the Department of Geology and Geophysics, Adelaide University, following procedures described by Elburg et al. (2001). Most of these were also analyzed for their $\mathrm{Sr}, \mathrm{Nd}$, and $\mathrm{Pb}$ isotopic compositions at Adelaide University on a Finnigan MAT 262 thermal ionization mass spectrometer operated in static mode. These XRF and isotopic results are reported in Foden et al. (2002a, $2002 b$ ). U-Pb analyses were carried out following techniques described by Elburg et al. (2003).

Zircons (figs. 3, 4) folded into filaments were analyzed by the evaporation technique (Kober 1986; Dougherty-Page and Bartlett 1999) on a Finnigan MAT 262 mass spectrometer at Adelaide University (complete data set available from the Journal of Geology office). Each of these enfolded zircons were analyzed in a series of heating steps. Data were collected in a static configuration, with ${ }^{206} \mathrm{~Pb}$, ${ }^{207} \mathrm{~Pb}$, and ${ }^{208} \mathrm{~Pb}$ collected in Faraday cups and the smaller ${ }^{204} \mathrm{~Pb}$ beam collected in a secondary electron multiplier. This allows very precise measurement of the ${ }^{204} \mathrm{~Pb} /{ }^{206} \mathrm{~Pb}$ ratio and hence precise common $\mathrm{Pb}$ corrections. Common $\mathrm{Pb}$ corrections were made using the Stacey and Kramers (1975) Pb crustal growth curve. Individual heating steps that gave common $\mathrm{Pb}$-corrected age errors (a product of the sum of the $2 \mathrm{SE}$ of ${ }^{207} \mathrm{~Pb} /{ }^{206} \mathrm{~Pb}$ and the ${ }^{204} \mathrm{~Pb} /{ }^{206} \mathrm{~Pb}$ used to make the common $\mathrm{Pb}$ correction) in excess of $10 \mathrm{Ma}(\approx 2 \%)$ were not included in further age calculations.

Using methods described by Dougherty-Page and Bartlett (1999) and Dougherty-Page and Foden (1996), efforts were made to maximize the number of heating steps in order to distinguish evaporation stages with discordant mixed-age $\mathrm{Pb}$. During successive heating steps of zoned zircons, it is unlikely that different-aged components will be repeatedly mixed in identical proportions, causing apparent age variation from one heating step to the next. Therefore, when the ages given by individual heating steps are plotted against their rank (fig. 5) within a sequence of ascending age, true ages will plot as near-horizontal plateaus, while mixing arrays will plot along lines of higher gradient. The points of inflection between these arrays may be used to discriminate between those steps that are dominated by a single component and those that contain mixed components.

To study the causes of any observed isotopic zonation, zircons from each of the samples were mounted and sectioned for backscattered electron 
Table 1. Detail of the Locality and Geological Relations of Dated South Australian Samples

\begin{tabular}{|c|c|c|c|c|c|c|c|c|c|c|}
\hline Locality & Lat. & Long. & Sample $^{\mathrm{a}}$ & $\begin{array}{l}\text { Sample no. } \\
\text { (table 2) }\end{array}$ & Rock type & Informal name & $\begin{array}{l}\text { Igneous } \\
\text { form }\end{array}$ & $\begin{array}{l}\text { Fabric } \\
\text { hosted }\end{array}$ & $\begin{array}{c}\text { Fabric } \\
\text { cut }\end{array}$ & $\begin{array}{l}\text { Delamerian } \\
\text { event dated }\end{array}$ \\
\hline \multicolumn{11}{|l|}{$\begin{array}{l}\text { Kinchina Quarry, } \\
\text { Murray Bridge/ }\end{array}$} \\
\hline Monarto & $35.05^{\circ} \mathrm{S}$ & $139.10^{\circ} \mathrm{E}$ & BC-M2 & MB1-2 & Granite & Monarto granite & Sill & $\mathrm{S} 2$ & $\mathrm{~S} 2$ & D2 \\
\hline Reedy Creek & $34.55^{\circ} \mathrm{S}$ & $139.13^{\circ} \mathrm{E}$ & $779-52$ & $01 \mathrm{RC} 183$ & Granodiorite & Reedy Creek granodiorite & Pluton & S3 & $\mathrm{S} 1 / \mathrm{S} 2$ & $>\mathrm{D} 3,<\mathrm{D} 2$ \\
\hline Reedy Creek & $34.55^{\circ} \mathrm{S}$ & $139.13^{\circ} \mathrm{E}$ & $779-5$ & $779-5$ & Quartz diorite & Reedy Creek diorite & Dike & None & S3 & $<\mathrm{D} 3$ \\
\hline Reedy Creek & $34.55^{\circ} \mathrm{S}$ & $139.13^{\circ} \mathrm{E}$ & SJF-9 & $01 \mathrm{RC} 1$ & Rhyolite & Felsic dike & Dike & None & S3 & $<\mathrm{D} 3$ \\
\hline Peake and Deni- & & & & & & & & & & \\
\hline $\begin{array}{l}\text { Son Ranges } \\
\text { Mannum Quarry }\end{array}$ & $\begin{array}{l}28.30^{\circ} \mathrm{S} \\
34.53^{\circ} \mathrm{S}\end{array}$ & $\begin{array}{l}136.00^{\circ} \mathrm{E} \\
139.21^{\circ} \mathrm{E}\end{array}$ & $\begin{array}{l}\text { PD9588 } \\
779-60\end{array}$ & $\begin{array}{l}\text { 02PD-1 } \\
\text { MAN-1 }\end{array}$ & $\begin{array}{l}\text { Monzonite } \\
\text { Mafic enclave }\end{array}$ & $\begin{array}{l}\text { Bungadillina monzonite } \\
\text { Mannum granite }\end{array}$ & $\begin{array}{l}\text { Stock } \\
\text { Pluton }\end{array}$ & $\begin{array}{l}\text { None } \\
\text { None }\end{array}$ & $\begin{array}{l}\text { Weak S1 } \\
\text { All }\end{array}$ & $\begin{array}{l}\text { D1 } \\
<\mathrm{D} 3\end{array}$ \\
\hline Padthaway & $35.45^{\circ} \mathrm{S}$ & $139.30^{\circ} \mathrm{E}$ & PG-11 & PG-11 & Syenite-granite & Marcollat granite & Pluton & None & All & $<\mathrm{D} 3$ \\
\hline
\end{tabular}

${ }^{a}$ Foden et al. $2002 b$.

(BSE) imaging, which principally highlights variations in $\mathrm{Zr} / \mathrm{Hf}$ ratio (Hanchar and Miller 1993).

\section{Results}

Details of our new U-Pb analytical results are given in tables 1 and 2 and figures 5 and 6, and they are summarized together with data from literature sources (table 3 ; fig. 7). $\mathrm{Pb}-\mathrm{Pb}$ evaporation data on zircons are reported in appendix tables A1-A3, available in the online edition or from the Journal of Geology office. In the following sections, the details of the geological context of the analyzed samples together with the implications of geochronological results are discussed.

Monarto Granite (Sample MB1-2). The folded, silllike, syn-D2 Monarto granite (this is sample BCM2 in Foden et al. 2002b) yielded zircons that are colorless and euhedral, with well-developed crystal faces showing fine oscillatory (magmatic) zonation overprinted by later post-D2 recrystallization. The degree of recrystallization of magmatic zonation is variable within the population, ranging from negligible to complete (fig. 3). Most crystals show some recrystallization. Twelve zircons were mounted as single-crystal loads and were analyzed in a total of 51 heating steps, of which 41 were used in further age determinations. These heating steps are plotted in order of ascending age in figure 5. Results are reported in appendix table A1.

As discussed by Dougherty-Page and Bartlett (1999), utilization of the $\mathrm{Pb}-\mathrm{Pb}$ evaporation method as a high-resolution geochronological tool in zircon populations with complex age structures requires the demonstration of within-error grouping of several heating step ages to form plateaus in ageranked diagrams (fig. 5). Rather than producing a single plateau, the Monarto granite zircon data generate a continuous trend between 492 and $507 \mathrm{Ma}$, with vague plateaus at 506 and $492 \mathrm{Ma}$, giving a collective mean age of $500+7 /-8 \mathrm{Ma}$. The range of ages within this population $(15 \mathrm{Ma})$ is much larger than anticipated for replicate analyses of a single concordant age population. We note that the Reedy Creek diorite (figs. 2, 4), discussed later, provides a good example of the degree of reproducibility expected in analysis of single-stage Cambrian zircons by the evaporation technique. The steepening in the array at $507 \mathrm{Ma}$ is taken to indicate the presence of some older inherited zircon with an age $>510 \mathrm{Ma}$. Clearly, the recrystallization observed in the BSE images (fig. 3) occurred after the initial magmatic crystallization, and the $500+$ 7/ $-8 \mathrm{Ma}$ age is interpreted (fig. 5) as a mean of two age components, one a magmatic crystallization event and the other a younger recrystallization event. We took the original magmatic crystallization age of the zircons to be defined by the 10 heating steps that form a subplateau at the upper end of this age range, giving an estimation for the (synD2) crystallization age of the Monarto granite of $506 \pm 1 \mathrm{Ma}$. The age of recrystallization is indicated by the coincidence of three heating step ages at $492 \pm 6 \mathrm{Ma}$ at the lowermost margin of the array. The heating step points 5-24 (fig. 5) are considered mixtures of these two age populations.

Because the zircon $\mathrm{Pb}-\mathrm{Pb}$ data suggest two phases of zircon growth, we separated monazite from the sample and undertook conventional U-Pb analysis (table 2), reasoning that the monazite may record the youngest high-temperature event. We also analyzed feldspar from the sample in order to make more accurate common $\mathrm{Pb}$ corrections. There is very close agreement between the concordant ${ }^{206} \mathrm{~Pb} /{ }^{238} \mathrm{U}-{ }^{207} \mathrm{~Pb} /{ }^{235} \mathrm{U}$ ages and both of the two-point (feldspar-monazite) ${ }^{238} \mathrm{U} /{ }^{204} \mathrm{~Pb}-{ }^{206} \mathrm{~Pb} /{ }^{204} \mathrm{~Pb}$ and ${ }^{235} \mathrm{U} /$ ${ }^{204} \mathrm{~Pb}{ }^{207} \mathrm{~Pb} /{ }^{204} \mathrm{~Pb}$ isochron ages. These are in the ranges $497 \pm 3.2 \mathrm{Ma}$ and $494 \pm 11 \mathrm{Ma}$, respectively. The concordia age is $493 \pm 1 \mathrm{Ma}$, and the ${ }^{207} \mathrm{~Pb} /{ }^{206} \mathrm{~Pb}$ age is $506 \pm 4 \mathrm{Ma}$. (fig. $6 \mathrm{~A}$ ). These results are consistent with the Kober data and suggest that although the Monarto granite might have an intrusive age $\sim 506 \mathrm{Ma}$, it was subsequently sub- 
Table 2. U-Pb Isotopic Analyses and Kober Evaporation $\mathrm{Pb}-\mathrm{Pb}$ Analyses

\begin{tabular}{|c|c|c|c|c|c|c|c|c|c|c|c|c|c|c|c|c|c|c|c|}
\hline \multirow[b]{2}{*}{ Sample } & \multirow[b]{2}{*}{ Locality } & \multirow[b]{2}{*}{ Mineral } & \multirow[b]{2}{*}{$\begin{array}{c}\mathrm{U} \\
(\mathrm{ppm})\end{array}$} & \multirow[b]{2}{*}{$\begin{array}{c}\mathrm{Pb} \\
(\mathrm{ppm})\end{array}$} & \multicolumn{14}{|c|}{ Ages (Ma) } & \multirow[b]{2}{*}{$\begin{array}{c}\% \\
\text { Discordance }\end{array}$} \\
\hline & & & & & ${ }^{206} \mathrm{~Pb} /{ }^{204} \mathrm{~Pb}$ & ${ }^{207} \mathrm{~Pb} /{ }^{204} \mathrm{~Pb}$ & ${ }^{208} \mathrm{~Pb} /{ }^{204} \mathrm{~Pb}$ & ${ }^{206} \mathrm{~Pb} /{ }^{238} \mathrm{U}^{*}$ & $\begin{array}{c}\text { Error } \\
\%\end{array}$ & ${ }^{207} \mathrm{~Pb} /{ }^{235} \mathrm{U}^{*}$ & $\begin{array}{c}\text { Error } \\
\%\end{array}$ & $\rho$ & ${ }^{206} \mathrm{~Pb} /{ }^{238} \mathrm{U}$ & \pm & ${ }^{207} \mathrm{~Pb} /{ }^{235} \mathrm{U}$ & \pm & ${ }^{207} \mathrm{~Pb} /{ }^{206} \mathrm{~Pb}$ & \pm & \\
\hline 02PD1 & PD & Titanite & 34.31 & 9.47 & 206.71 & 26.45 & 492.98 & .083 & .18 & .658 & 1.27 & .45 & 513.0 & .4 & 513.2 & .7 & 513.6 & 3.5 & .04 \\
\hline $01 \mathrm{RC} 183$ & $\mathrm{RC}$ & Titanite & 85.77 & 23.72 & 125.66 & 21.72 & 287.31 & .079 & 1.73 & .621 & .55 & .17 & 490.5 & .6 & 490.8 & 2.7 & 492.8 & 14.4 & .05 \\
\hline $01 \mathrm{RC} 183$ & $\mathrm{RC}$ & Zircon & Kober & & & & & & & & & & & & & & 492.6 & 1.0 & \\
\hline $779 / 5$ & $\mathrm{RC}$ & Zircon & Kober & & & & & & & & & & & & & & 491.0 & 1.0 & \\
\hline $01 \mathrm{RC} 1$ & $\mathrm{RC}$ & Titanite & 125.96 & 22.55 & 422.62 & 38.63 & 608.64 & .078 & .52 & .615 & .63 & .60 & 486.0 & .5 & 486.5 & .6 & 488.4 & 2.9 & .11 \\
\hline MB1-2 & MB & Monazite & 6032.12 & 1614.41 & 416.00 & 38.43 & 1087.09 & .080 & .75 & .632 & .40 & .97 & 495.2 & 3.7 & 497.3 & 3.2 & 506.4 & 4.3 & .42 \\
\hline MB1-2 & MB & Zircon & Kober & & & & & & & & & & & & & & 506.0 & 1.0 & \\
\hline MB1-2 & MB & Zircon & Kober & & & & & & & & & & & & & & 492.0 & 6.0 & \\
\hline PG11 & PG & Zircon & 448.00 & 39.00 & 2153.00 & 137.11 & 466.45 & .078 & .97 & .615 & .55 & .96 & 487.8 & 4.7 & 486.5 & 2.2 & 488.7 & 3.8 & .27 \\
\hline \multirow[t]{2}{*}{ MAN-1 } & MAN & Titanite & 6.59 & 1.11 & 149.27 & 23.05 & 179.58 & .071 & .11 & .568 & .17 & .54 & 444.4 & .5 & 456.6 & .8 & 498.1 & 3.9 & 2.6 \\
\hline & & & & & & & & & & & & & & \multicolumn{6}{|c|}{ Isochrons } \\
\hline Sample & Locality & Mineral & $\underset{(\mathrm{ppm})}{\mathrm{U}}$ & $\begin{array}{c}\mathrm{Pb} \\
(\mathrm{ppm})\end{array}$ & ${ }^{206} \mathrm{~Pb} /{ }^{204} \mathrm{~Pb}$ & ${ }^{207} \mathrm{~Pb} /{ }^{204} \mathrm{~Pb}$ & ${ }^{208} \mathrm{~Pb} /{ }^{204} \mathrm{~Pb}$ & ${ }^{238} \mathrm{U} /{ }^{204} \mathrm{~Pb}$ & $\underset{\%}{\text { Error }}$ & ${ }^{235} \mathrm{U} /{ }^{204} \mathrm{~Pb}$ & $\underset{\%}{\text { Error }}$ & & & $\begin{array}{l}{ }^{238} \mathrm{U} / /^{204} \mathrm{~Pb} \\
{ }^{206} \mathrm{~Pb} /{ }^{204} \mathrm{~Pb}\end{array}$ & ${ }^{206} \mathrm{~Pb} /{ }^{204} \mathrm{~Pb}(\mathrm{I})$ & $\begin{array}{l}{ }^{235} \mathrm{U} /{ }^{204} \mathrm{~Pb} \\
{ }^{207} \mathrm{~Pb} /{ }^{204} \mathrm{~Pb}\end{array}$ & ${ }^{207} \mathrm{~Pb} /{ }^{204} \mathrm{~Pb}(\mathrm{I})$ & & \\
\hline 02PD1 & PD & Titanite & 34.31 & 9.47 & 206.71 & 26.45 & 492.98 & 2279.401 & .10 & 16.532 & .10 & & & & & & & & \\
\hline 02PD1 & $\mathrm{PD}$ & Feldspar & 1.91 & 17.67 & 19.15 & 15.63 & 39.62 & .092 & .29 & .001 & .29 & & & $509.8 \pm 5.5$ & 19.14 & $511.6 \pm 1.4$ & 15.63 & & \\
\hline $01 \mathrm{RC} 183$ & $\mathrm{RC}$ & Titanite & 85.77 & 23.72 & 125.66 & 21.72 & 287.31 & 1362.626 & .17 & 9.883 & .17 & & & & & & & & \\
\hline $01 \mathrm{RC} 183$ & $\mathrm{RC}$ & Feldspar & 4.11 & 8.49 & 20.33 & 15.71 & 40.39 & 32.378 & .20 & .235 & .20 & & & $491.2 \pm 3.6$ & 17.77 & $491.8 \pm 1.8$ & 15.57 & & \\
\hline $01 \mathrm{RC} 1$ & $\mathrm{RC}$ & Titanite & 125.96 & 22.55 & 422.62 & 38.63 & 608.64 & 5168.481 & .13 & 37.485 & .13 & & & & & & & & \\
\hline $01 \mathrm{RC} 1$ & $\mathrm{RC}$ & Feldspar & 1.42 & 9.70 & 19.31 & 15.68 & 41.47 & 9.793 & .37 & .071 & .37 & & & $485.0 \pm 10$ & 18.54 & $485.7 \pm 1.3$ & 15.63 & & \\
\hline MB1-2 & MB & Monazite & 6032.12 & 1614.41 & 416.00 & 38.43 & 1087.09 & 4985.678 & .96 & 36.160 & .96 & & & & & & & & \\
\hline MB1-2 & MB & Feldspar & 1.91 & 17.67 & 19.15 & 15.63 & 39.62 & .092 & .29 & .001 & .29 & & & $494 \pm 11$ & 19.14 & $496.6 \pm 3.9$ & 15.63 & & \\
\hline MAN-1 & MAN & Titanite & 6.59 & 1.11 & 149.27 & 23.05 & 179.58 & 1811.145 & .15 & 13.136 & .15 & & & & & & & & \\
\hline MAN-1 & MAN & Feldspar & 1.09 & 13.99 & 20.05 & 15.71 & 40.14 & 5.156 & .15 & .037 & .15 & & & $445.5 \pm 4.9$ & 19.68 & \pm 18 & 15.68 & & \\
\hline
\end{tabular}

Note. Analyses made using a Finnigan 262 multicollector thermal ionization mass spectrometer. Localities: PD = Peake and Denison Ranges, RC $=$ Reedy Creek, MB $=$ Murray

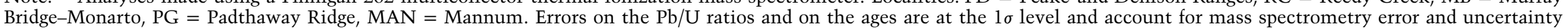
in the mass fractionation correction and a $5 \%$ error on the assumed common $\mathrm{Pb}$ composition. 


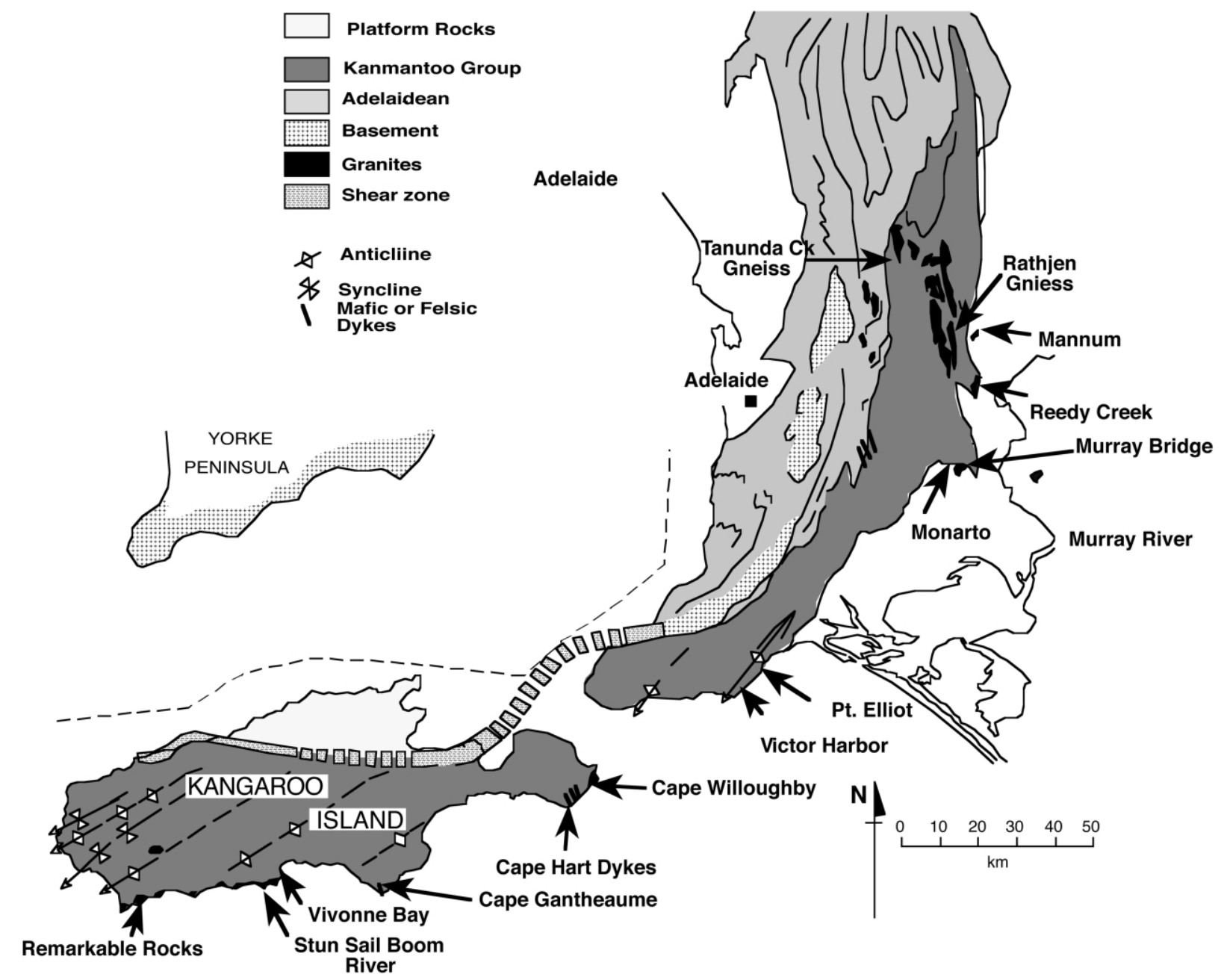

Figure 2. Detail of the geology of the southern Adelaide Fold Belt (Delamerian Orogen) showing the locality of dated samples.

jected to a high- $T$ event at $493 \mathrm{Ma}$. In the quarry that exposes the Monarto granite, very coarsegrained, undeformed quartz-feldspar-muscovitebiotite pegmatite crosscuts all other fabrics and lithologies. Intrusion of these undeformed pegmatites clearly postdated regional cooling below $400^{\circ} \mathrm{C}$, and the muscovite ${ }^{40} \mathrm{Ar} /{ }^{39} \mathrm{Ar}$ age of $478 \pm$ $2 \mathrm{Ma}$ dates their synchronous intrusion and cooling (Burtt and Phillips 2002).

Reedy Creek. Zircons were separated from the strongly foliated granodiorite and undeformed diorite whose emplacement brackets the terminal Delamerian D3 deformation at Reedy Creek (table 1). These were subjected to evaporation $\mathrm{Pb}-\mathrm{Pb}$ analysis. BSE images of zircons from the granodiorite (sample 01RC183) show fine oscillatory (magmatic) zonation. Inherited cores were clearly present in the population, and several of the zircons showed etched and slightly embayed crystal faces (fig. 4A), indicating a postintrusive resorption event. Overgrowth rims with oscillatory zonation are evidence of later magmatic growth during the diorite intrusion. The age data for the granodiorite are plotted in order of ascending age in figure $5 \mathrm{~B}$. Twelve filaments were loaded with zircons: six with large single crystals and six with between three and six smaller crystals of similar size and morphology. A total of 58 heating steps were collected, of which 43 gave age errors of $<10 \mathrm{Ma}$ and were used in further age calculations. The data give an age plateau with a well-defined upper boundary at $495 \pm 2 \mathrm{Ma}$ and a lower boundary of $489 \pm 7 \mathrm{Ma}$. Heating steps 

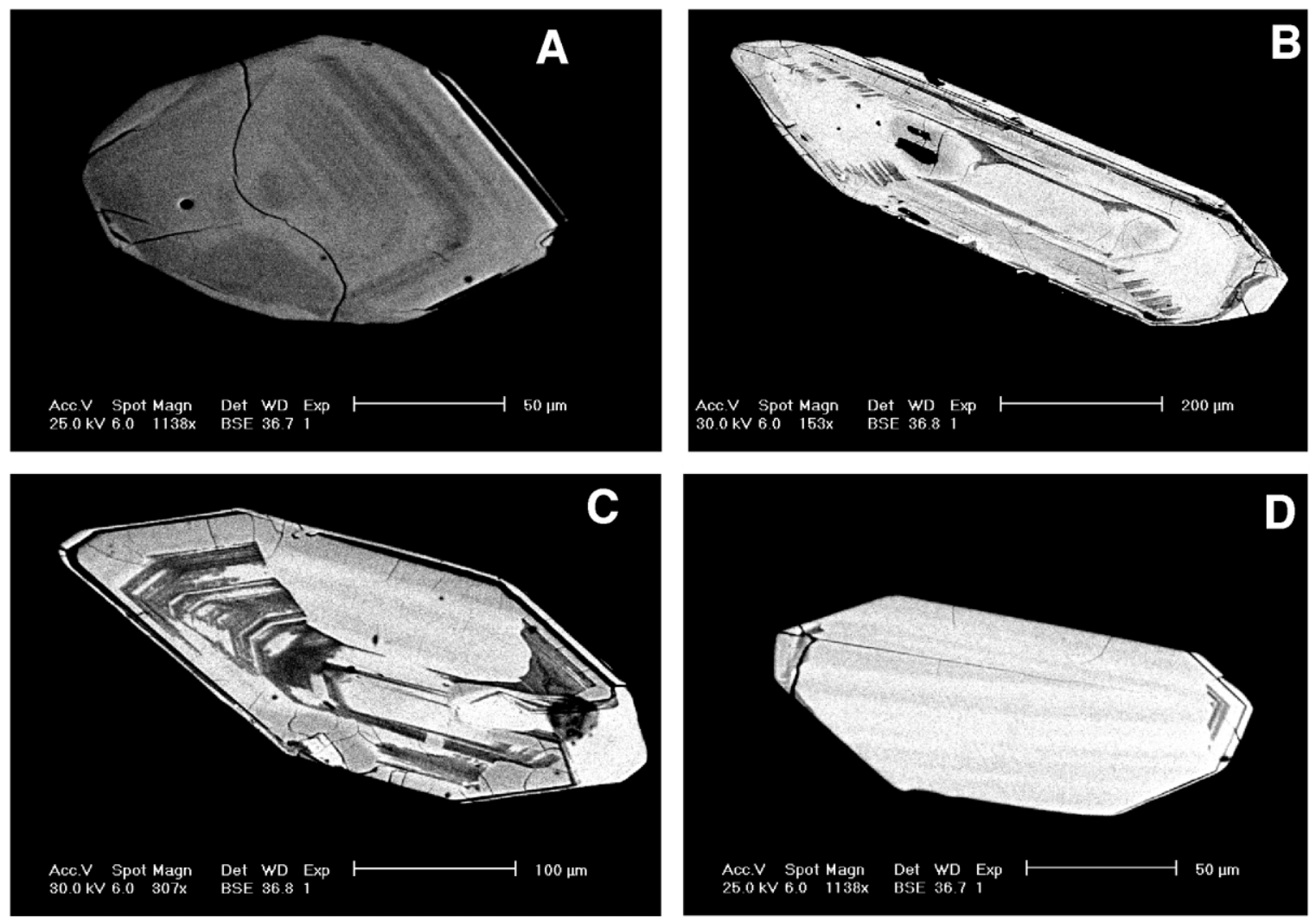

Figure 3. Backscattered electron images of zircons from the Monarto granite (Kinchina Quarry), Murray Bridge. The zircons show varying degrees of patchwork replacement. $A$, Original magmatic oscillatory zonation. $B$, Oscillatory zonation overprinted within the pyramids of the crystal. $C$, Overprinting of oscillatory zonation from the prism margin (note relict original zonation). $D$, Almost total recrystallization. Only pyramid tips show original zonation.

within the age plateau give a mean age of $493 \pm$ $1 \mathrm{Ma}(2 \sigma)$. Results are reported in appendix table A2.

The larger zircons from the diorite (779/5) have very similar morphologies to those from the granodiorite (fig. 4), indicating possible inheritance, and are consistent with the observed disaggregation of granodiorite blocks collapsed into the intruding diorite. To minimize the possibility of analyzing inherited xenocrysts, only small acicular zircons (a morphology not present in the granodiorite) were analyzed. Individual acicular crystals did not supply sufficient $\mathrm{Pb}$ for analysis, so several (6-10) were loaded into each filament. Seven filaments were analyzed in a total of 37 heating steps. Of these, 26 gave age errors of $<2 \%( \pm<10 \mathrm{Ma})$ and were used in the age calculations (fig. $5 C$ ). Analysis of the $\mathrm{Pb}$ evaporated from the diorite during each of the heating steps give a very well-defined age plateau with a younger limit of $489 \pm 5 \mathrm{Ma}$ and an older limit at $493 \pm 4 \mathrm{Ma}$. The mean value of the ages forming this plateau is $491 \pm 1 \mathrm{Ma}(2 \sigma$; fig. $5 C)$. By selecting a single morphological zircon type, our results have successfully isolated a single phase of zircon crystallization for the Reedy Creek diorite. The range within the age-heating step plateau (5 m.yr.) represents a good example of the degree of reproducibility anticipated in the analysis of single-stage Cambrian zircons by the evaporation technique. However, it is clear that despite the data quality, the granodiorite and crosscutting diorite have identical ages within error. This $(492 \pm 2 \mathrm{Ma})$ must also therefore be the age of the terminal D3 Delamerian deformation at Reedy Creek and is the same as that of the younger magmatic event affecting the Monarto granite south of Reedy Creek. Results are reported in appendix table A3.

In order to review and refine the ${ }^{207} \mathrm{~Pb}-{ }^{206} \mathrm{~Pb}$ zircon evaporation results, we also collected U-Pb data (table 2) from titanites from the granodiorite (sam- 

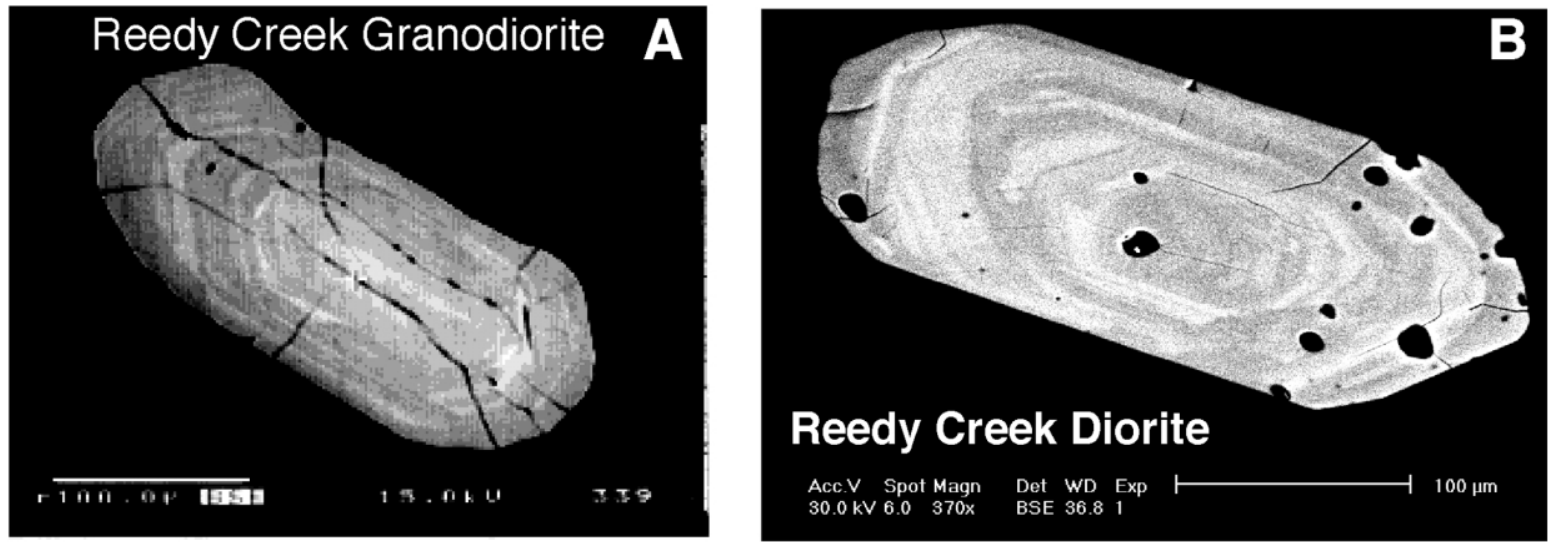

Figure 4. A, Backscattered electron image of a zircon from the Reedy Creek granodiorite (01RC183; table 2). The crystal shows primary magmatic oscillatory zonation with some slight widening and overprinting of original growth zones. The faces of the crystal are slightly etched. B, Backscattered electron image of a zircon from the Reedy Creek diorite (779/5) showing primary oscillatory magmatic zonation and large rounded inclusions.

ple 01RC183; table 2) and from late (post-D3) undeformed felsic dikes (sample 01RC1; table 2) that cut both granodiorite and diorite. In each case, we also analyzed feldspars as a means of making accurate common $\mathrm{Pb}$ corrections. For the granodiorite, the ${ }^{206} \mathrm{~Pb} /{ }^{238} \mathrm{U}$ and ${ }^{207} \mathrm{~Pb} /{ }^{235} \mathrm{U}$ ages and both the two-point ${ }^{238} \mathrm{U} /{ }^{204} \mathrm{~Pb}-{ }^{206} \mathrm{~Pb} /{ }^{204} \mathrm{~Pb}$ and ${ }^{235} \mathrm{U} /{ }^{204} \mathrm{~Pb}$ ${ }^{207} \mathrm{~Pb} /{ }^{204} \mathrm{~Pb}$ isochron values yield ages in the range $490.5 \pm 0.6$ to $491.8 \pm 1.8 \mathrm{Ma}$. The concordia age was $490.5 \pm 2 \mathrm{Ma}$ (fig. $6 A$ ), and ${ }^{207} \mathrm{~Pb} /{ }^{206} \mathrm{~Pb}$ age was $493 \pm 14 \mathrm{Ma}$. These results are completely compatible with the evaporation results and suggest a weighted average U-Pb age of $492 \pm 1.5 \mathrm{Ma}$.

Titanite from the felsic dike (01RC1) yielded ${ }^{206} \mathrm{~Pb} /{ }^{238} \mathrm{U}$ and ${ }^{207} \mathrm{~Pb} /{ }^{235} \mathrm{U}$ ages and two-point ${ }^{238} \mathrm{U} /$ ${ }^{204} \mathrm{~Pb}-{ }^{206} \mathrm{~Pb} /{ }^{204} \mathrm{~Pb}$ and ${ }^{235} \mathrm{U} /{ }^{204} \mathrm{~Pb}-{ }^{207} \mathrm{~Pb} /{ }^{204} \mathrm{~Pb}$ isochron values in the range $486.5 \pm 0.6 \mathrm{Ma}$ to $485 \pm 10 \mathrm{Ma}$. The concordia age is $486 \pm 2 \mathrm{Ma}$ (fig. $6 A$ ), and ${ }^{207} \mathrm{~Pb}$ / ${ }^{206} \mathrm{~Pb}$ age is $488 \pm 3 \mathrm{Ma}$. These ages are younger and statistically different from the ages of the granodiorite and diorite and consistent with the sequence of intrusive events. They place a minimum age on the cessation of Delamerian deformation at Reedy Creek of $\sim 486$ Ma.

Mannum and Padthaway. The undeformed Mannum pluton (Turner and Foden 1996) is a high-level, potassic, rapakivi, (A-type) syeno-granite. The intrusion has limited outcrop, but total magnetic intensity imagery shows that it clearly crosscuts the Reedy Creek pluton and is part of an extensive series of posttectonic A-type granites and lavas with associated mafic dikes and enclaves that extend to the southeast into Victoria (Turner et al. 1992). The age of this pluton provides a minimum age of the termination of the Delamerian deformation in the southeastern Mount Lofty ranges.

The Mannum granite (fig. 1) hosts swarms of enclaves that result from mingling of a mafic magma with the host granite. As demonstrated by Turner and Foden (1996), the mafic enclaves and granite show initial Sr-isotopic equilibrium and are probably different fractionation and mingling stages of the same parent magma. Based on a recalculation of the whole-rock $\mathrm{Rb}-\mathrm{Sr}$ isotope data published by Turner and Foden (1996) using ISOPLOT (Ludwig 1999), the eight-point model 1 (see Ludwig 1999) $\mathrm{Rb}$-Sr isochron is $482.3 \pm 4.5 \mathrm{Ma}$. In southeast South Australia (Padthaway Ridge; fig. 1), these post-Delamerian plutons are associated at the same structural level with contemporary felsic volcanic rocks (Turner et al. 1992; Foden et al. 1990). This observation and evidence for shallow intrusion of the Mannum granite provided by the fine grain size of the first-stage intrusion and miarolitic cavities indicate that the upper amphibolite facies Delamerian metamorphic complexes (Alias et al. 2002) were nearly exhumed before being intruded by these late granite complexes.

We collected conventional zircon U-Pb isotopic data (table 2) from one of the posttectonic granites (the Marcollat granite) from Padthaway (PG11 in Turner et al. 1992; Foden et al. 2002b). This granite yields very large euhedral zircons without cores and yields a concordant age of $487 \pm 1.2 \mathrm{Ma}$ (fig. $6 D$ ). The posttectonic granite ages from both Mannum and the Padthaway Ridge are consistent with the 

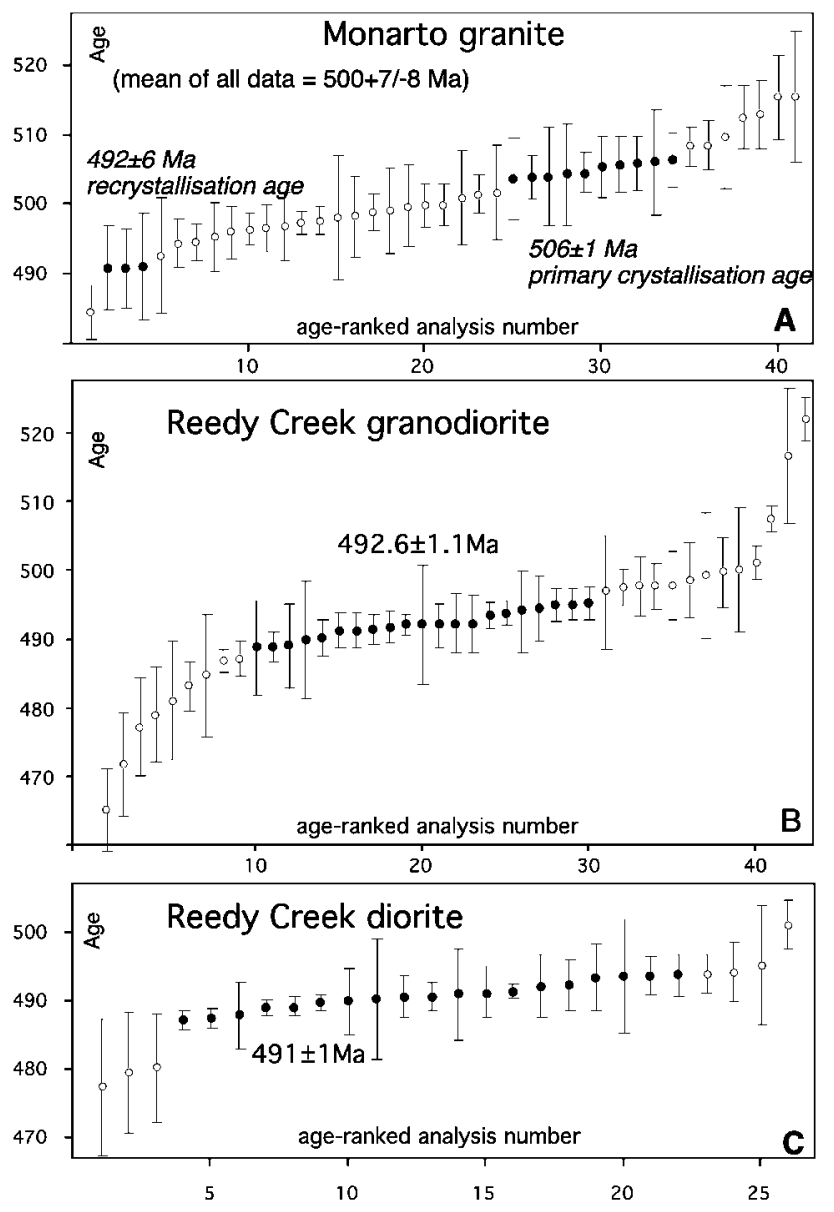

Figure 5. Stepwise zircon evaporation ${ }^{207} \mathrm{~Pb} /{ }^{206} \mathrm{~Pb}$ age versus heating step (ranked in order of age) diagrams. A, Monarto granite (MB1-2). The apparent mean crystallization age is $500+7 /-8 \mathrm{Ma}$ representing a mixing line between the age of primary magmatic crystallization at $506 \pm 1 \mathrm{Ma}$ and the age of recrystallization at $492 \pm 6$ Ma. $B$, Reedy Creek granodiorite (01RC183), which gives a crystallization age of $492.6 \pm 1.1 \mathrm{Ma}$. $C$, Reedy Creek diorite (779/5), which gives a crystallization age of $491 \pm 1 \mathrm{Ma}$. Solid symbols are the heating step plateau data used in age calculations. Each point is the analysis of a single heating step, representing between 24 and 120 determinations of each mass peak. The error bars denote the sum of 2 SEs on the ${ }^{204} \mathrm{~Pb} /{ }^{206} \mathrm{~Pb}$ and ${ }^{207} \mathrm{~Pb} /{ }^{206} \mathrm{~Pb}$ determinations. A complete tabulation of these analytical data are available from J. Foden on request.

Reedy Creek data, indicating that the final Delamerian deformation was older than $488 \pm 2 \mathrm{Ma}$ and probably close to $492 \pm 2 \mathrm{Ma}$. A large titanite crystal that grew within the mafic enclaves in the Mannum granite was dated and gave an age of $449 \pm$ $5 \mathrm{Ma}$ (two-point titanite-feldspar ${ }^{238} \mathrm{U} /{ }^{204} \mathrm{~Pb}-{ }^{206} \mathrm{~Pb} /$ ${ }^{204} \mathrm{~Pb}$ isochron). This is similar to ages obtained for a magmatic-hydrothermal event in the Mount Painter Inlier (Elburg et al. 2003), located farther north in the Adelaide Fold Belt.

South Coast of Kangaroo Island. The Delamerian magmatic evolution exposed on Kangaroo Island (figs. 1, 2) has been discussed in detail by Foden et al. $(2002 b)$. On the south coast at Vivonne Bay and at the Stun'sail Boom River mouth, migmatite complexes involve the development and segregation of biotite granodiorite diatexite by in situ partial melting of Kanmantoo Group greywackes. These complexes are intruded by potassium feldspar megacrystic S-type granites that are contemporary with intermingled migmatite melts. The granite at Stun'sail Boom River yielded a SHRIMP $\mathrm{U}-\mathrm{Pb}$ zircon age of $503 \pm 4 \mathrm{Ma}$ (Fanning 1990). The biotite granodiorite diatexite is syntectonic; it has a moderately developed approximately northerly dipping $\left(30^{\circ}-50^{\circ}\right)$ biotite foliation. This is the youngest known fabric in this part of the orogenic belt and the igneous intrusive age of the megacrystic granite puts a maximum limit of $503 \pm 4 \mathrm{Ma}$ on the end of the Delamerian contraction in this part of the belt.

East of Vivonne Bay, along the south coast of Kangaroo Island, the deformed Kanmantoo Group sequence is intruded by numerous composite dolerite-S-type rhyolite dikes (Foden et al. 2002b). These dikes are vertical and have a strongly clustered NW $\left(325^{\circ}\right)$ orientation. They postdate the Delamerian deformation hosted by the diatexitemigmatite-granite suites described above, intruding perpendicular to the regional fabric. A SHRIMP $\mathrm{U}$-Pb zircon age of $500 \pm 7 \mathrm{Ma}$ (Fanning 1990) of these dikes therefore provides a minimum age of the cessation of Delamerian deformation in this part of the belt, possibly between 8 and 12 m.yr. earlier than the final deformation $150 \mathrm{~km}$ to the northeast at the Reedy Creek.

\section{Discussion}

Timing and Duration of Delamerian Events. The $522 \pm 2-\mathrm{Ma}$ age of zircons from a tuff horizon in the uppermost Normanville Group (Cooper et al. 1992; Jenkins et al. 2002) constrains the maximum age of the initiation of the deep-water turbidite deposition in the Kanmantoo Trough (Stansbury Ba$\sin$ ) to be mid-Early Cambrian (table 3; fig. 7). The dating of the earliest syntectonic granite in the belt (the Rathjen Gneiss; Foden et al. 1999) at $514 \pm 4$ Ma defines the commencement of basin inversion and the onset of Delamerian contraction. The commencement of the Delamerian Orogeny therefore 

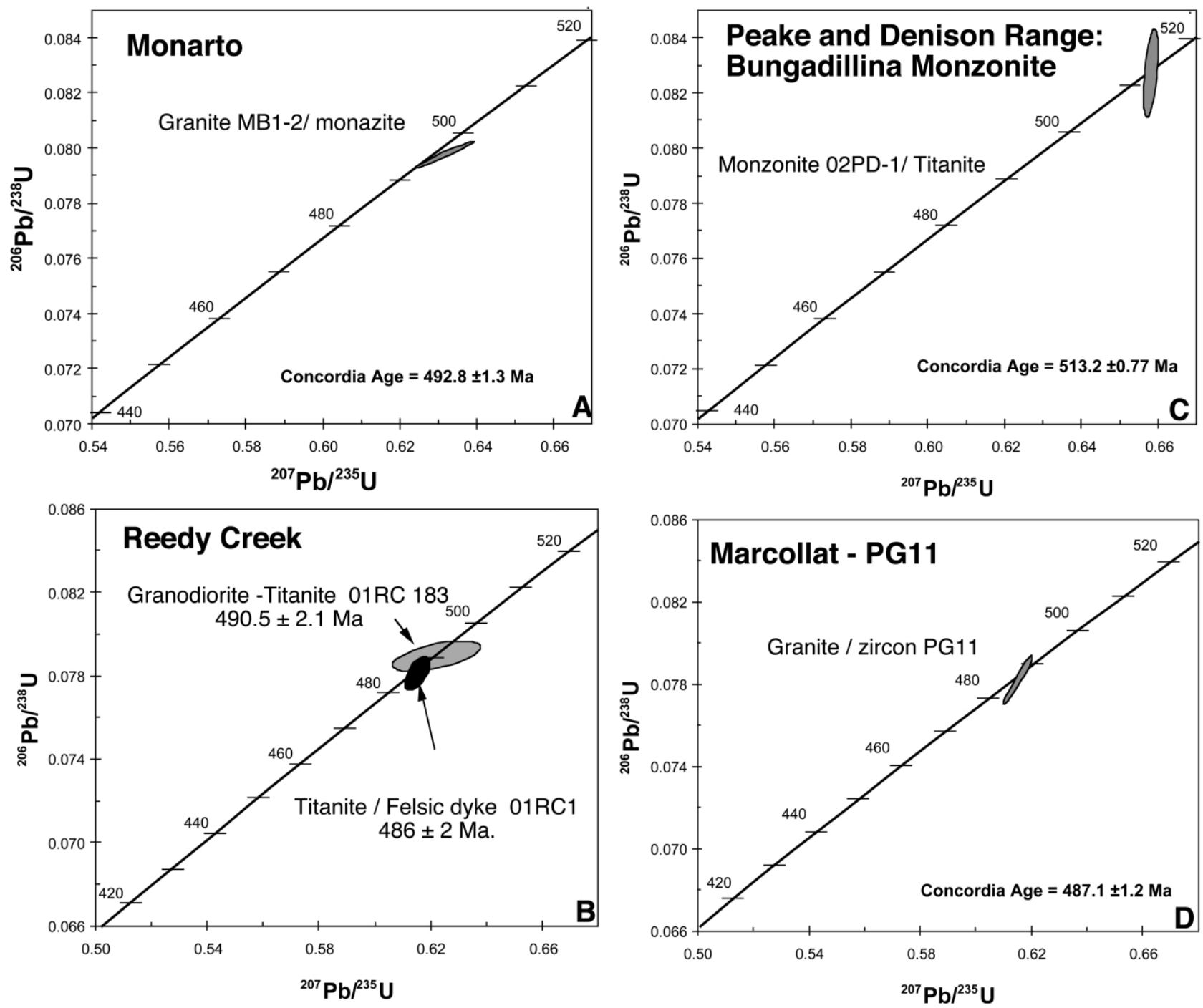

Figure 6. U-Pb concordia diagrams showing analyses of minerals from felsic igneous rocks from the Adelaide Fold Belt (Delamerian Orogen; fig. 2). Thermal ionization mass spectrometry analytical data (of 5-10-mg multigrain populations with similar morphology and size) plotted in each of the concordia figures are reported in table 2. A, Monazite from the syn-Delamerian Monarto granite. B, Titanite from the late Delamerian (D3) granodiorite and from an undeformed, post-Delamerian rhyolite dike at Reedy Creek. $C$, Titanite from the early syn-Delamerian Bungadallina monzonite from the Peake and Denison Ranges in the northern Delamerian Orogen (Morrison and Foden 1990). D, Zircon from the post-Delamerian Marcollat granite in the Padthaway Ridge area of SE South Australia (fig. 1).

followed a maximum of $8 \pm 6 \mathrm{~m}$.yr. of sediment deposition (fig. 7). This age of initial granite formation is repeated at widely dispersed localities around the belt, including the Peake and Denison Ranges (Bungadillina monzonite; Morrison and Foden 1990) in the far north $(513 \pm 0.8 \mathrm{Ma}$; table 2), quartz porphyry intrusions in the Victorian Glenelg Inlier (514 $\pm 3 \mathrm{Ma}$; SHRIMP U-Pb on zircon; Ireland et al. 2002), and the Heazlewood tonalite in western Tasmania $(510 \pm 3 \mathrm{Ma}$; SHRIMP $\mathrm{U}-\mathrm{Pb}$ on zircon; Turner et al. 1998). Our dating of events at Reedy Creek indicates that the end of Delamerian deformation took place at $492 \pm 2 \mathrm{Ma}$ (and certainly before intrusion of the felsic dikes and sills at $487 \mathrm{Ma}$ ). This is the same as the age in the Glenelg Zone where the termination of the deformation is bracketed by the Wando tonalite (493 $\pm 8 \mathrm{Ma}$; SHRIMP U-Pb on zircon) and Loftus Creek granodiorite $(491 \pm 8 \mathrm{Ma}$; SHRIMP U-Pb on zircon; Ireland et al. 2002; fig. 7). We also note that this was probably later than the end of deformation at the westernmost limit of the orogen in southern 
Table 3. A Summary of New and Previously Published Geochronological Results from the Delamerian Orogen in South Australia and the Glenelg Inlier in Western Victoria (These Data Are Plotted in Fig. 7)

\begin{tabular}{|c|c|c|c|c|c|c|}
\hline \multirow{2}{*}{$\begin{array}{l}\text { Number } \\
\text { in figure } 7 \\
1\end{array}$} & \multicolumn{2}{|c|}{ Age (Ma) } & Locality & Rock type & Reference & Method \\
\hline & 478 & 2 & Murray Bridge & Pegmatite & Burtt and Phillips 2003 & Ar-Ar \\
\hline 2 & 482.3 & 4.5 & Mannum & Granite & Turner and Foden 1996 & $\mathrm{Rb}-\mathrm{Sr}$ isochron \\
\hline 3 & 484 & 7 & Loftus Creek (Glenelg, Victoria) & Granodiorite & Ireland et al. 2002 & SHRIMP \\
\hline 4 & 485.7 & 3.8 & Anabama & Granodiorite & Foden et al. $2002 b$ & Kober \\
\hline 5 & 486 & .5 & Reedy Creek & Rhyolite dike & This article & ${ }^{206 / 238} \mathrm{U}-\mathrm{Pb}$ \\
\hline 6 & 487.1 & 1.2 & Marcollat & Syenite & This article & U-Pb concordia \\
\hline 7 & 487 & 5 & Black Hill & Gabbro & Milnes et al. 1977 & $\mathrm{~K}-\mathrm{Ar}$ \\
\hline 8 & 491 & \pm & Reedy Creek & Diorite & This article & Kober \\
\hline 9 & 491 & \pm & Loftus Creek (Glenelg, Victoria) & Granodiorite & Ireland et al. 2002 & SHRIMP \\
\hline 10 & 492 & \pm & Murray Bridge/Monarto & Granite & This article & Kober \\
\hline 11 & 492.6 & 1.1 & Reedy Creek & Granodiorite & This article & Kober \\
\hline 12 & 493 & 7 & Windsong & Rhyodacite lava & $\begin{array}{l}\text { A. C. Burtt and C. M. Fanning, } \\
\text { PIRSA database }\end{array}$ & SHRIMP \\
\hline 13 & 493 & \pm & Wando (Glenelg, Victoria) & Tonalite & Ireland et al. 2002 & SHRIMP \\
\hline 14 & 495.2 & 3.7 & Murray Bridge & Granite & This article & ${ }^{206 / 238} \mathrm{U}-\mathrm{Pb}$ \\
\hline 15 & 496 & 8 & Arkaroola & Leucogranite & Elburg et al. 2003 & $\mathrm{Sm} / \mathrm{Nd}$ isochron \\
\hline 16 & 499 & \pm 12 & Arkaroola & Pegmatite & Elburg et al. 2003 & $\mathrm{Rb} / \mathrm{Sr}$ isochron \\
\hline 17 & 500 & \pm 7 & Cape Ganthaume (KI) & Granite & Fanning 1990 & SHRIMP \\
\hline 18 & 503 & \pm 4 & Stun'sail Boom River(KI) & Granite & $\begin{array}{l}\text { A. C. Burtt and C. M. Fanning, } \\
\text { PIRSA database }\end{array}$ & SHRIMP \\
\hline 19 & 503 & \pm & Rathjen & Granite & Foden et al. 1999 & SHRIMP \\
\hline 20 & 504 & \pm & Stun'sail Boom River(KI) & Granite & $\begin{array}{l}\text { A. C. Burtt and C. M. Fanning, } \\
\text { PIRSA database }\end{array}$ & SHRIMP \\
\hline 21 & 506 & \pm & Arkaroola & Leucogranite & Elburg et al. 2003 & $\mathrm{Sm} / \mathrm{Nd}$ isochron \\
\hline 22 & 506 & 1 & Murray Bridge & Granite & This article & Kober \\
\hline 23 & 509 & \pm & Cape Willoughby (KI) & Granite & Fanning 1990 & SHRIMP \\
\hline 24 & 513 & .8 & Peake and Denison ranges & Monzonite & This article & U-Pb concordia \\
\hline 25 & 513.4 & 4 & Tanunda Creek & Granite & A. C. Burtt, PIRSA database & SHRIMP \\
\hline 26 & 514 & \pm & Quartz porphyry & Granite dike & Ireland et al. 2002 & SHRIMP \\
\hline 27 & 514 & \pm & Rathjen & Granite & Foden et al. 1999 & Kober/SHRIMP \\
\hline 28 & 521 & \pm & Teal Flat Volcanics & Felsic volcanics & Burtt et al. 2000 & SHRIMP \\
\hline \multirow[t]{14}{*}{29} & 522 & \pm 2 & Norm Group tuff & Tuff & Jenkins et al. 2002 & SHRIMP \\
\hline & Coolin & g ages: & & & & \\
\hline & 480 & \pm 4 & Reedy Creek & Migmatite & Turner et al. 1996 & Ar-Ar \\
\hline & 485 & \pm 10 & Marcollat & Syenite & Turner et al. 1996 & Ar-Ar \\
\hline & 485 & \pm 5 & Glenelg & Granite & Turner et al. 1996 & Ar-Ar \\
\hline & 486 & \pm 5 & Reedy Creek felsic & Granite & Turner et al. 1996 & Ar-Ar \\
\hline & 486 & \pm 3 & Taratap & Granite & Turner et al. 1996 & Ar-Ar \\
\hline & 486 & \pm 9 & Marne mylonite & Felsic mylonite & Turner et al. 1996 & Ar-Ar \\
\hline & 487 & \pm 3 & Willalooka & Granite & Turner et al. 1996 & Ar-Ar \\
\hline & 487. & $4 \pm 3.5$ & Stun'sail Boom River (KI) & Granite & Foden et al. $2002 b$ & $\mathrm{Rb}-\mathrm{Sr}$ \\
\hline & 490 & \pm 4 & Palmer & Granite & Turner et al. 1996 & Ar-Ar \\
\hline & 490 & \pm 6 & Wando & Granodiorite & Turner et al. 1996 & $\mathrm{Ar}-\mathrm{Ar}$ \\
\hline & 493 & \pm 5 & Rathjen & Granite & Turner et al. 1996 & Ar-Ar \\
\hline & 496 & \pm 2 & Normanville & Sheared granite & Turner et al. 1996 & Ar-Ar \\
\hline
\end{tabular}

Note. $\quad \mathrm{KI}=$ Kangaroo Island. PIRSA $=$ Primary Industries and Resources, South Australia.

Kangaroo Island, where it must have occurred between $504 \mathrm{Ma}$ (deformed S-type granite at Stun'sail Boom River; fig. 2; Fanning 1990; C. M. Fanning, personal communication, 2004) and $500 \mathrm{Ma}$ (undeformed felsic dikes at Cape Gantheaume; fig. 2). It is probable that the late deformation stages are diachronous-the product of localized crustal strain due to thermal weakening in the vicinity of magmatic intrusions emplaced into a prevailing stress field. New $\mathrm{Rb}-\mathrm{Sr}$ and $\mathrm{Sm}-\mathrm{Nd}$ isochrons on deformed leucogranites in the Arkaroola-Mount Painter area in the north also lie in the range $506 \pm 9$ and $496 \pm 8 \mathrm{Ma}$, respectively, indicating a maximum age of cessation of Delamerian contraction of $499 \pm 12 \mathrm{Ma}$, based on the Rb-Sr age of a deformed pegmatite (Elburg et al. 2003). The Delamerian contraction therefore continued for a maximum of $24 \pm 5$ m.yr. (fig. 7).

The onset of deformation was synchronous with the commencement of granite production. This timing is defined by the magmatic ages of the earliest syntectonic granites, such as the $514 \pm 4-\mathrm{Ma}$ Rathjen Gneiss (Foden et al. 1999). As discussed by Foden et al. (2002b), these granites are the products of interaction between melts from decompressed asthenospheric mantle and the contemporaneous rift basin filling sediments. They range from I- to S-type. The cessation of Delamerian deformation was marked by a change to posttectonic bimodal, substantially mantle-derived magmatism (Turner 


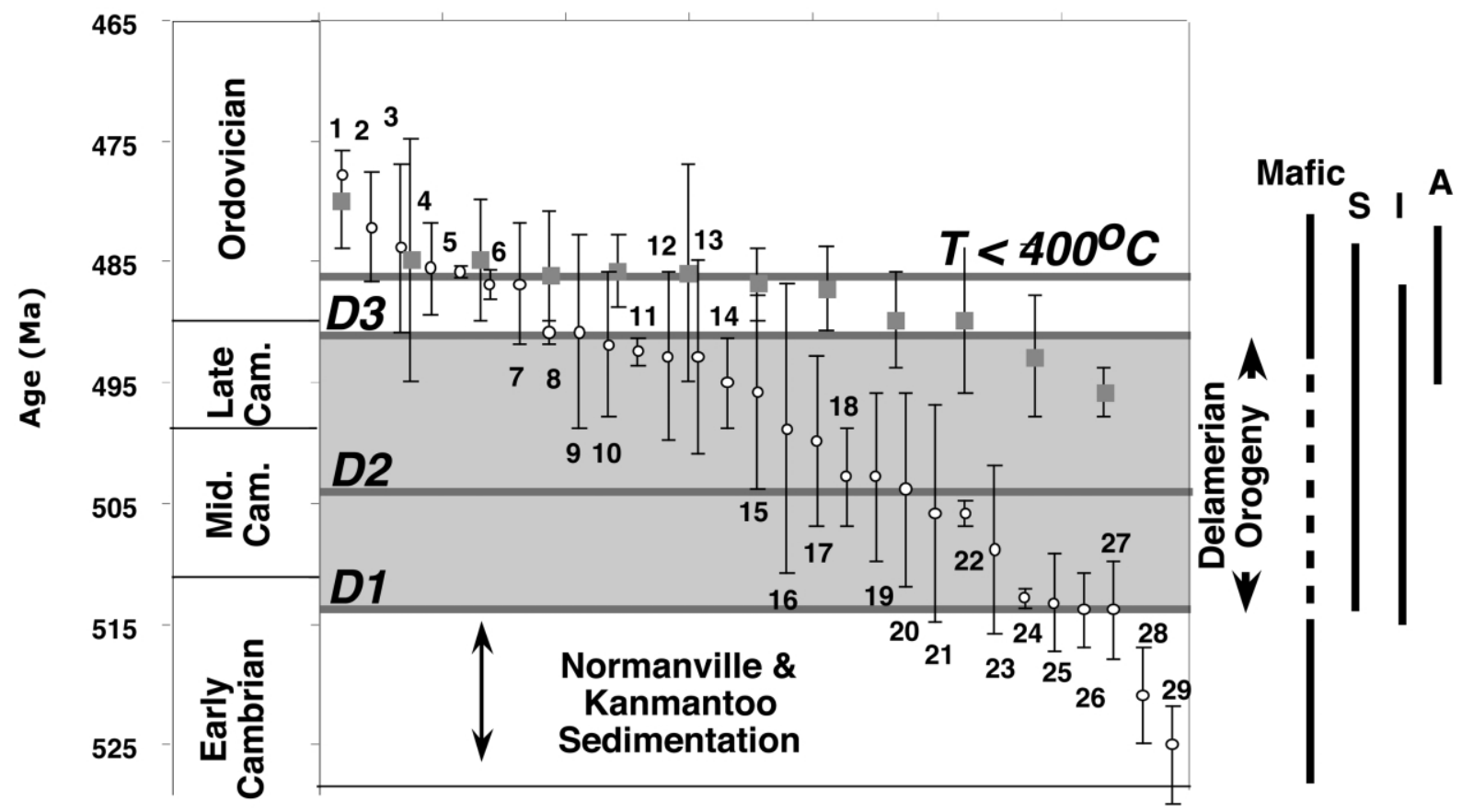

Figure 7. Summary of the available Delamerian geochronology with $2 \sigma$ uncertainties, from this article and from the literature. The source of each individual analysis numbered 1-29 is given in table 3 . These data are all magmatic emplacement ages. The shaded band (514-490 Ma) indicates the duration of Delamerian deformation. Data points marked by gray unnumbered squares are cooling ages (mostly ${ }^{40} \mathrm{Ar}-{ }^{39} \mathrm{Ar}$ on biotite or hornblende), and these are listed in table 3. The South Australian sequence of magmatic events through the Delamerian period is also indicated (Foden et al. 2002b).

et al. 1992; Turner and Foden 1996; Foden et al. $2002 a, 2002 b$ ), comprising A-type granite and mafic intrusions. This phase of magmatism occurred in the Early Ordovician from 493 to $480 \mathrm{Ma}$ and implies a renewed influx of hot mantle beneath the belt, possibly associated with the combined effects of lithospheric extension and lithospheric mantle detachment.

In Tasmania, the earliest recognized Delamerian event is the proposed obduction of ultramafic complexes onto Early Cambrian passive margin basalt sediment sequences (Berry and Crawford 1988; Crawford and Berry 1992). This occurred before the deposition of the partly molassic marine turbidites of the late Middle and Late Cambrian Dundas Group. The $510 \pm 3 \mathrm{Ma}$ U-Pb SHRIMP age of the Heazlewood tonalite (Turner et al. 1998) constrains the timing of this Delamerian D1 event, and as in the Adelaide Fold Belt, it occurs close to the EarlyMiddle Cambrian boundary. In Tasmania, the Middle to Late Cambrian is characterized by widespread intermediate to felsic volcanism of the Mount Read Volcanics and the Tyndall Group. U$\mathrm{Pb}$ SHRIMP ages (Perkins and Walsh 1993) of these range from $503 \pm 4 \mathrm{Ma}$ (Mount Charter rhyolite) to $494 \pm 4 \mathrm{Ma}$ (Comstock Tuff). These ages are synchronous with late D2 to D3 events in the Adelaide Fold Belt and consistent with the limited, localized deformation of the Tasmanian samples.

Comparisons with the Ross Orogen in Antarctica. Our Delamerian geochronology (fig. 7) provides a good basis to make comparisons with the Ross Orogen. Recent studies (Pankhurst et al. 1988; Goodge and Dallmeyer 1992, 1996; Goodge et al. 1993a, 1993b; Millar and Storey 1995; Encarnacion and Grunow 1996; Goodge 1997) provide a comprehensive geochronological picture of the age of the Ross Orogen based on good-quality, mostly U-Pb zircon dates (fig. 8). Data from North and South Victoria Land and the central Transantarctic Mountains indicate the onset of major intermediate to felsic volcanism and intrusion occurred at $250 \mathrm{Ma}$, following on from the Neoproterozoic Beardmore Orogeny (Rowell et al. 1993; Encarnacion and Grunow 1996). The commencement of the Ross Orogeny has been interpreted to be the result of major plate reorganization and the start of subduction (Encarnacion and Grunow 1996; Goodge 1997). 
Sedimentation occurred in localized basins and together with continuation of granite intrusion, deformation, and metamorphism through to the Late Cambrian. As Myrow et al. (2002) point out, sedimentary basin formation and sediment generation through this period are probably direct consequences of Ross tectonism. The undeformed Granite Harbour intrusives and related pegmatite and volcanics range from 505 to $485 \mathrm{Ma}$ (fig. 8). Volcaniclastic rocks in the Thiel Mountains are also undeformed and have an age of $500 \mathrm{Ma}$ (Pankhurst et al. 1988). These results indicate that the Ross Orogen had a history of active convergent or transpressional tectonism (Goodge et al. 1993a, 1993b) that continued for $\sim 35 \mathrm{~m}$.yr. starting with the first appearance of orogenic magmatism at least as early as $540 \mathrm{Ma}$ (Goodge et al. 1993a, 1993b). Clearly by comparison with the Delamerian Orogen that forms the Australian end of the belt, the Ross had an orogenic history that started much earlier. In fact, felsic magmatism, deformation, and metamorphism continued for $>25$ m.yr. in the Ross before it started in the Adelaide Fold Belt, where the oldest Cambrian granite is $514 \mathrm{Ma}$ (Foden et al. 1999). In the Adelaide Fold Belt, much of this time interval was occupied by sedimentary basin formation with associated mantle-derived magmatism. The Kanmantoo Group in particular is at least $7 \mathrm{~km}$ thick and was deposited in only $\sim 8$ m.yr. (Haines et al. 2001), requiring a very high rate of sediment supply. Zircon provenance studies (Ireland et al. 1998) have demonstrated that the turbidite-rich Kanmantoo Group has a large population of detrital zircons with Early Cambrian ages as well as Grenville- and Pan-African-aged populations. As also observed by Wombacher and Münker (2000), these have no obvious sources to the west of the fold belt. Haines et al. (2001) show that basal turbidite current directions imply sediment supply to the Kanmantoo Trough from the south. The implications of our data support this conclusion very firmly, implying derivation of the sediments from that part of the Ross-Delamerian orogen to the south that was experiencing tectonic shortening and rapid erosion before basin inversion had commenced at the Australian end to the north.

Goodge and Dallmeyer (1996) provide a series of ${ }^{40} \mathrm{Ar}^{39} \mathrm{Ar}$ cooling ages (fig. 8) from the Geologists Range in the central Transantarctic Mountains and from the Lanterman Range in Northern Victoria Land. Their evidence suggests contrasting behavior of the more southern part of the Ross Orogen and the part closest to Australia. In the central Transantarctic Mountains, cooling that resulted from uplift and erosion started as early as $539 \pm 5 \mathrm{Ma}$ and

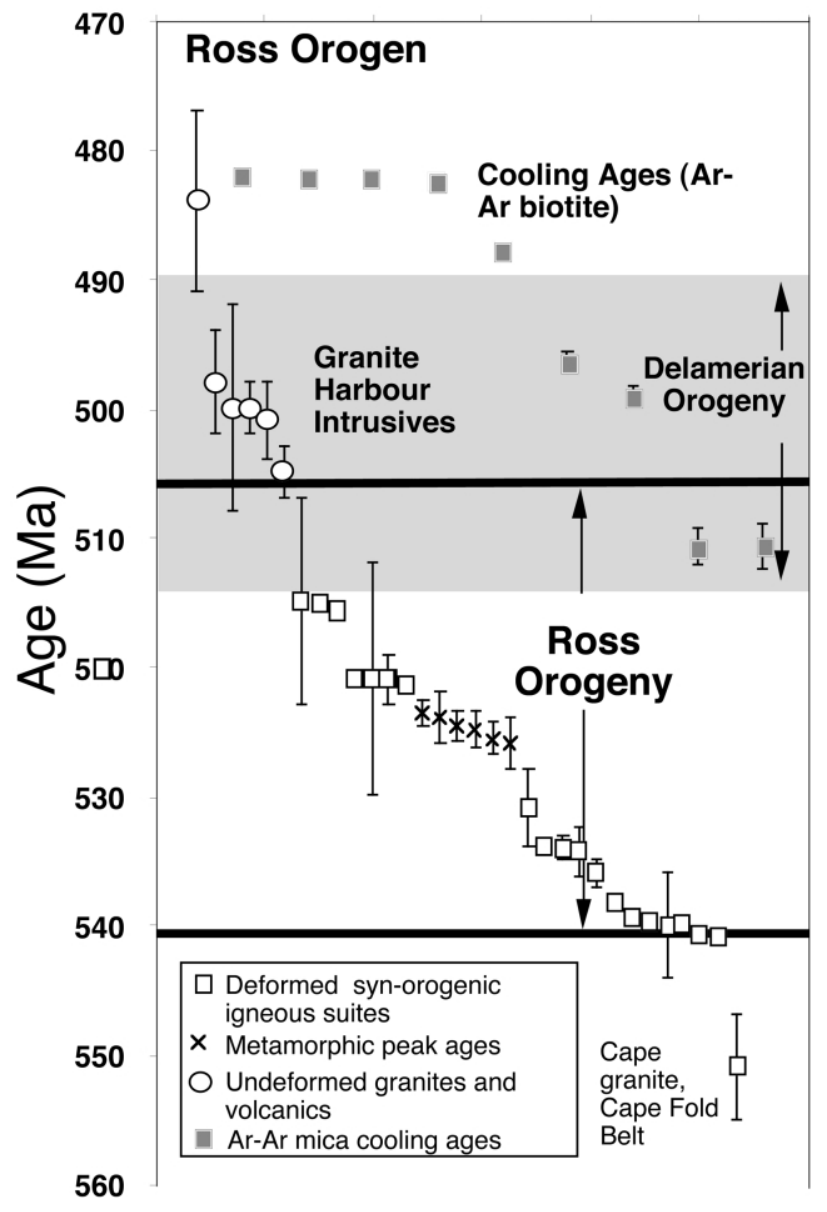

Figure 8. A summary of superior-quality geochronological data largely based on U-Pb zircon dating from the Ross Orogen (see the text for data sources). As indicated, these are igneous or high-grade metamorphic ages. The age limits of SE Australian Delamerian deformation from figure 7 are indicated. The figure clearly indicates that the Ross orogenic activity commenced $\sim 25 \mathrm{~m}$.yr. before the Delamerian deformation started. However, the cooling ages from the Ross are very similar to those from the Delamerian and suggest rapid terminal exhumation at $\sim 490 \mathrm{Ma}$.

possibly accounts for the sediment supplied northward to the Kanmantoo Trough. Cooling below the muscovite closure temperature finally occurred at $\sim 495 \mathrm{Ma}$. By contrast, Northern Victoria Land has cooling ages very similar to those in the Delamerian Fold Belt, with hornblende and muscovite ages in the range 488-482 $\mathrm{Ma}$, implying rapid cooling $\left(30^{\circ} \mathrm{C} / \mathrm{Ma}\right)$, very fast uplift $(1.2 \mathrm{~mm} / \mathrm{yr})$, and erosion (Goodge and Dallmeyer 1996).

The Ross Orogen extends, as the Cape Fold Belt, into southernmost Africa, where very rapid exhumation, cooling, and erosion rates are also reported 
(Armstrong et al. 1999). The syntectonic Cape Granite there has a U-Pb SHRIMP zircon age of $540 \pm 4 \mathrm{Ma}$ and ${ }^{40} \mathrm{Ar} /{ }^{39} \mathrm{Ar}$ muscovite and biotite cooling ages of $536 \pm 1 \mathrm{Ma}$.

Pan-African. Gondwana accreted from several major and probably numerous smaller continental and oceanic arc fragments during the very loosely defined "Pan-African" orogenies (Fitzsimons 2000; Boger et al. 2001; Boger and Miller 2004; Collins and Pisarevsky 2005). This accretion took place over a broad period from $\sim 850$ to $520 \mathrm{Ma}$ (Dalziel 1991; Pinna et al. 1993; Powell et al. 1994; Grunow et al. 1996), with the main accretion (fig. 10) occurring from 650 to $520 \mathrm{Ma}$ (Meert 2003; Collins and Pisarevsky 2005). Through closure and convergence in the Mozambique suture (fig. 9) that peaked at $620 \mathrm{Ma}$ (Meert 2003), the East African Orogeny assembled western Gondwana. This suture also extends south into Antarctica (Jacobs et al. 1998), from where more recent interpretations have suggested that a second suture radiated from Dronning Maud Land. This passed northeast through the southern Prince Charles Mountains to Prydz Bay (Boger et al. 2001; Meert 2003) and separated an Australian-east Antarctic continental fragment from an Indian block (fig. 9). Boger et al. (2001) have suggested that tectonic activity followed by postcollision cooling (Mezger and Cosca 1999; Rickers et al. 2000) associated with the final stages of Gondwanan assembly continued in this belt from 550 to $490 \mathrm{Ma}$ (Kuunga Orogeny of Meert 2003). These conclusions are also supported by recent results from the Leeuwin Complex in southwestern West Australia (fig. 10), where granulite facies metamorphism and syntectonic granite magmatic suites have a mean age of $537 \pm 4 \mathrm{Ma}$ and extend from $\sim 600 \mathrm{Ma}$ to $522 \pm 5 \mathrm{Ma}$ (Collins 2003).

As illustrated in figure 10, the peak of the PanAfrican events in Antarctica-Africa and India occurred between 630 and $540 \mathrm{Ma}$ but had commenced as long ago as $900 \mathrm{Ma}$ (Pinna et al. 1993). A number of recent geochronological studies in the Namibian Damara Orogen in southern Africa have also revealed Middle to Late Cambrian static metamorphism and posttectonic felsic magmatism (510-480 Ma; Jung and Mezger 2001; Jung et al. 2001; Meert 2003), the ages of which are like those of the late Ross and Delamerian orogens. These are imposed on a mobile belt whose main synkinematic activity was earlier (570-550 Ma; Jung and Mezger 2001) and associated with active plate convergence, subduction, and accretion. Interestingly, like the model we proposed earlier for the Delamerian, the occurrence of late A-type granite in the Damara Orogen has also been ascribed to mantle influx following lithospheric delamination (Jung et al. 1998, 2001).

The Pan-African ages (fig. 10) mostly correspond to the time of Neoproterozoic to Early Cambrian passive marginal activity in eastern Australia. The age cluster marking the Delamerian corresponds to the time of rapid decline in Pan-African events and indicates a shift in the locus of strain to what had been the trailing edge of the Australia-Antarctic continent as it became part of the new greater Gondwana supercontinent.

Convergence and the Delamerian Orogeny. An important conclusion from our results is that the Delamerian and Ross orogens have common latemagmatic and cooling histories and were both the result of stress transfer to the trailing passive margin following Gondwanan supercontinent assembly. However, particularly toward its southern (Weddell Sea) end, the Ross commenced its subduction-related orogenic history at least 25 m.yr. before Delamerian deformation and subduction commenced in Australia and during which time the basin into which the Kanmantoo Group sediments were deposited continued in extension. Consistent with this conclusion, it has been proposed that the Kanmantoo Trough was developed as a jog on a leftlateral E-W transcurrent fault south of the present Australian southern margin and that this fault separated Pacific margin sectors of Australia and Antarctica (Flöttmann et al. 1998). The delayed onset of subduction during the opening of the Kanmantoo Trough in the Delamerian zone implies that westward motion of the Australian portion of eastern Gondwana continued to be accommodated by either subduction or deformation of its western margin in either the Mozambique or more probably in the northern end of the southern Prince Charles Mountains-Prydz Bay suture during the Middle to Late Cambrian. Such a scenario is consistent with recent geochronological results in the latter suture (Collins and Pisarevsky 2005). This conclusion is very well supported by the $522 \pm 5$-Ma age of terminal mobile orogenesis in the Leeuwin Complex (fig. 10) in southwestern West Australia (Collins 2003). This complex is part of the Australian craton and predates Delamerian initiation, but it is synchronous with the Ross Orogeny.

Deformation in the Ross Orogen before the Delamerian provides an obvious source for the sediments in the Kanmantoo Trough, with their distinctive Early Cambrian- and Grenvillean-aged detrital zircon populations (Ireland et al. 1998). This is also the probable source for the Early to Middle Cambrian Haupiri Group sediments in the Takaka Terrane in New Zealand. These are inter- 


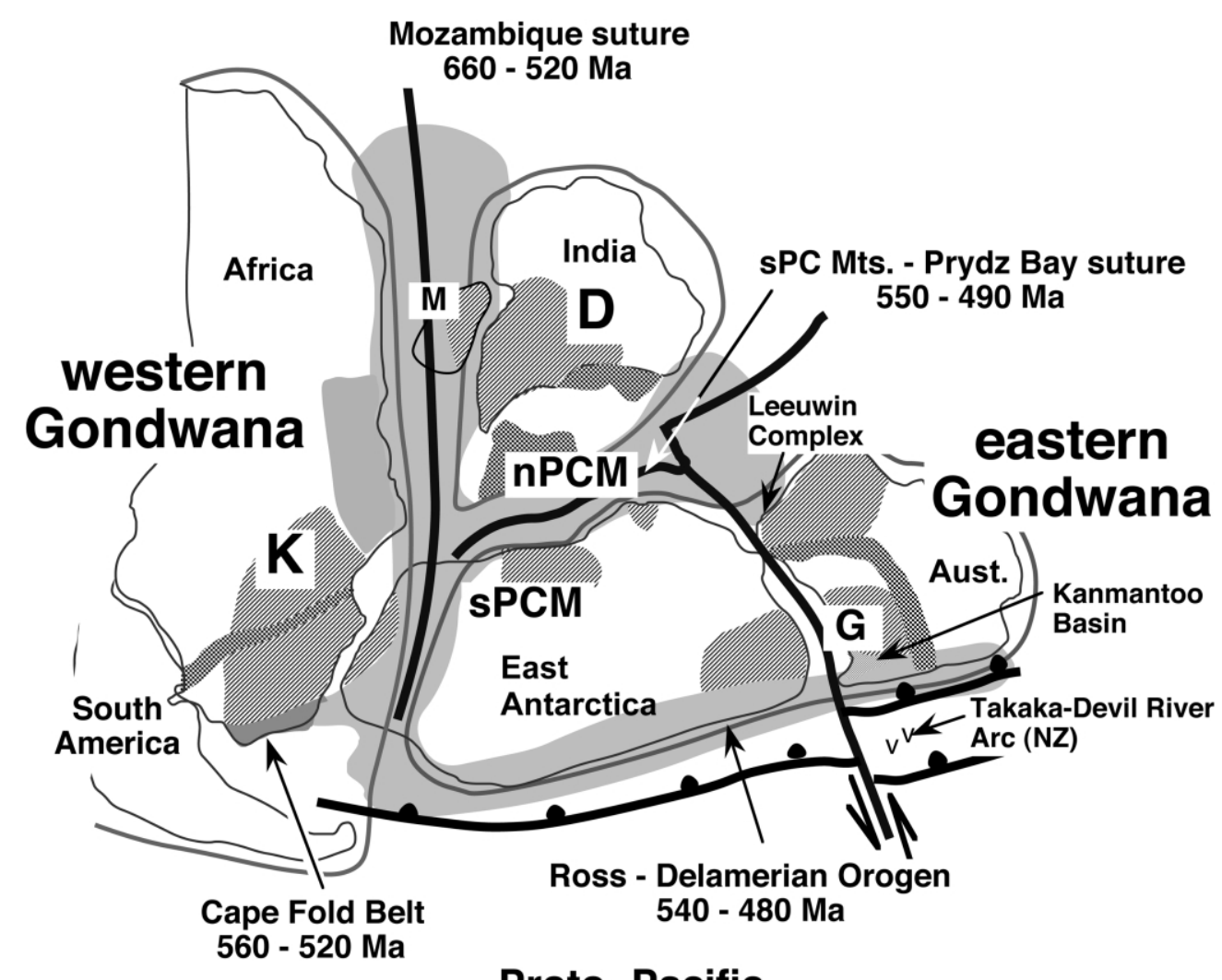

Proto- Pacific

Figure 9. The assemblage of continental fragments constituting Gondwana (after Boger and Miller 2004). Pale shading = Late Proterozoic to Cambrian mobile belts, diagonal striping = Paleoproterozoic to Archaean cratonic nuclei, checkered zones $=$ Grenville-age mobile belts, $K=$ Kalahari craton, $s P C M=$ South Prince Charles Mountains, $n P C M=$ North Prince Charles Mountains, $M=$ Madagascar, $D=$ Dharwar craton, and $G=$ Gawler craton.

preted to have been deposited in a back arc basin to the west of the Devil River Volcanic arc, leading to the conclusion that for this volcanic arc to receive sediments from the Ross Highlands, it must have been on the same plate and thus above a westdipping subduction zone south of any postulated Australia-Antarctic fault (Wombacher and Münker 2000).

By contrast with the Ross Orogen, it has been suggested that the earliest stage of subduction along the Australian Pacific margin was eastward and that the Delamerian Orogeny resulted from collision and obduction of postulated outboard arc complexes on the Pacific plate across the Australian margin (Crawford and Berry 1992; Münker and Crawford 2000). This conclusion is mainly based on the interpretation that the Early Cambrian Tasmanian boninite ultramafic complexes are of forearc origin and were emplaced as far-traveled allochthons by westward obduction of the Pacific plate (Berry and Crawford 1988; Crawford and Berry
1992; and see fig. 3A, 3B in Boger and Miller 2004). This model has had long acceptance but must be called into question by recent results, including those reported here. Boninite-related magmas that have clearly intruded the attenuated continental margin have been reported in the Victorian Glenelg Zone (Kemp 2003). These are not allochthonous, and their generation would require westward subduction. These Victorian boninites are likely to have the same magmatic age ( $514 \mathrm{Ma})$ as those in Tasmania (Turner et al. 1998) and those of the onset of Delamerian orogenesis in Tasmania and in South Australia (Foden et al. 1999, 2002a), of the boninite/ arc association in the Takaka/Devil River/Mount Benson terrane in New Zealand (Münker 2000; Münker and Crawford 2000), and of earliest granite formation in the Victorian Glenelg Zone. Because these ages all indicate the simultaneous appearance of subduction-type magmatism and of contractional deformation, we infer that the synchronicity 


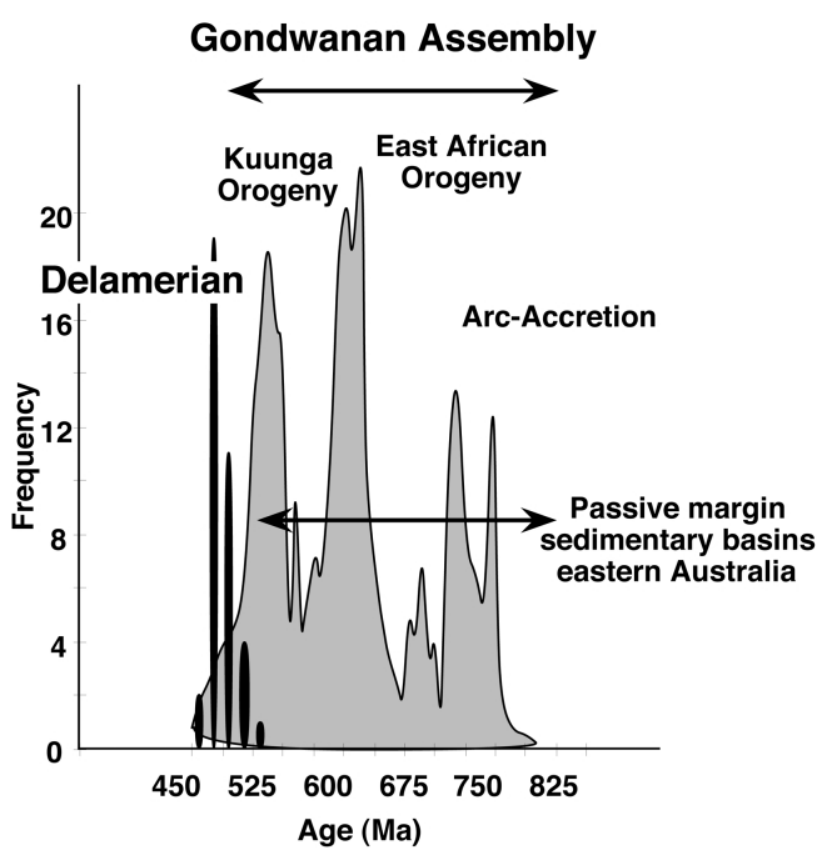

Figure 10. Age-frequency diagram depicting Delamerian ages (table 3 ) compared with those from the events defining the assembly of Gondwana (from Meert 2003; largely based on $\mathrm{U}-\mathrm{Pb}$ and $\mathrm{Pb}-\mathrm{Pb}$ geochronological data from the literature). The East African Orogeny and preceding arc accretion events are loosely described as the Pan-African Orogeny. The "late" Pan-African Kuunga Orogeny (Meert 2003) is the consequence of final assembly of western and eastern Gondwanan components.

of these events implies that this is the age of inception of subduction (fig. 11).

Because volcanism in the Takaka-Devil River arc commenced at the same time as that on the Australian continental margin in South Australia, Victoria, and Tasmania, it implies that the oceanic Takaka system must have been an offshore, synchronous (parallel) subduction system (as indicated in figs. 9, 11) or an along-strike oceanic extension of the eastern Australian system.

It is hard to reconcile eastward subduction at 514 Ma with the presence of synorogenic granitic magmatism in the Adelaide Fold Belt on what would (in that interpretation) have been the underthrusting plate. Had the period before the Delamerian Orogeny been one of Early Cambrian eastward subduction, then the synchronicity of this with the extension of the South Australian Kanmantoo Trough, with its associated E-MORB mafic magmatism (Foden et al. 2002a), is also difficult to explain. Our conclusion is that the Delamerian Orogeny was not driven by accretion or collision with (hypothetical) offshore arcs or continental frag- ments but is mainly the consequence of the transfer of far-field (ridge-push?) stresses to the previously attenuated continental margin at the beginning of subduction. Strain from this event was heterogeneously partitioned across the continental margin, becoming focused in thermally weakened, attenuated crust of prior rifts (fig. 11).

We therefore conclude that the Delamerian is an orogenic event driven by the inception of subduction in this part of the Gondwanan margin and is a response to the changing plate dynamics brought about by the completion of subduction and collision to the western side that produced Gondwana (Boger et al. 2001; Boger and Miller 2004; Collins and Pisarevsky 2005).

Termination of the Delamerian-Ross Orogeny. A number of lines of evidence suggest that Delamerian convergent deformation terminated abruptly at the end of the Cambrian and was associated with rapid buoyant uplift and exhumation. We reach this conclusion because ${ }^{40} \mathrm{Ar}^{-39} \mathrm{Ar}$ and $\mathrm{Rb}-\mathrm{Sr}$ ages of detrital mica and ${ }^{40} \mathrm{Ar}-{ }^{39} \mathrm{Ar}$ cooling ages do not span the age of the orogen; instead, they cluster at the age of the termination of deformation $1 \sim 503-490$ $\mathrm{Ma}$; Turner et al. 1996). This tectonic transition was marked by changes in the composition of felsic magmas, from syntectonic I-S-type granites to bimodal mantle-derived, magmatic suites that include siliceous, potassic, posttectonic A-type granites and volcanics (Turner et al. 1992; Turner 1996; Turner and Foden 1996; Foden et al. 2002b). Terminal Delamerian exhumation exposed and eroded the syntectonic metamorphic and igneous complexes that the A-type granites and volcanics intruded at high crustal level. ${ }^{40} \mathrm{Ar}-{ }^{39} \mathrm{Ar}$ dating (Turner et al. 1996) of detrital micas from the dominantly Ordovician flysch (Cas 1983; Fergusson et al. 1989) in the Lachlan Fold Belt reveal that these have Late Delamerian ages of very limited range. This indicates that the eroding terrain was being very rapidly exhumed through the $350^{\circ}-450^{\circ} \mathrm{C}$ Ar-muscovite/ biotite closure temperature (Turner et al. 1996).

Those ages, mostly from the literature, that reflect closure during cooling are illustrated in figure 7. These were determined mostly on biotite from granites and gneisses in the Adelaide Fold Belt and the Glenelg Zone. The ages fall in a narrow range from 492 to $485 \mathrm{Ma}$ and are only slightly younger than the age of cessation of deformation reported in this article (i.e., $\sim 490 \mathrm{Ma}$ at Reedy Creek), which was determined by U-Pb methods with high closure temperatures. Importantly, the ${ }^{40} \mathrm{Ar}-{ }^{39} \mathrm{Ar}$ age of hornblende (Turner et al. 1996) from the Marcollat A-type granite is indistinguishable from its $\mathrm{U}-\mathrm{Pb}$ 


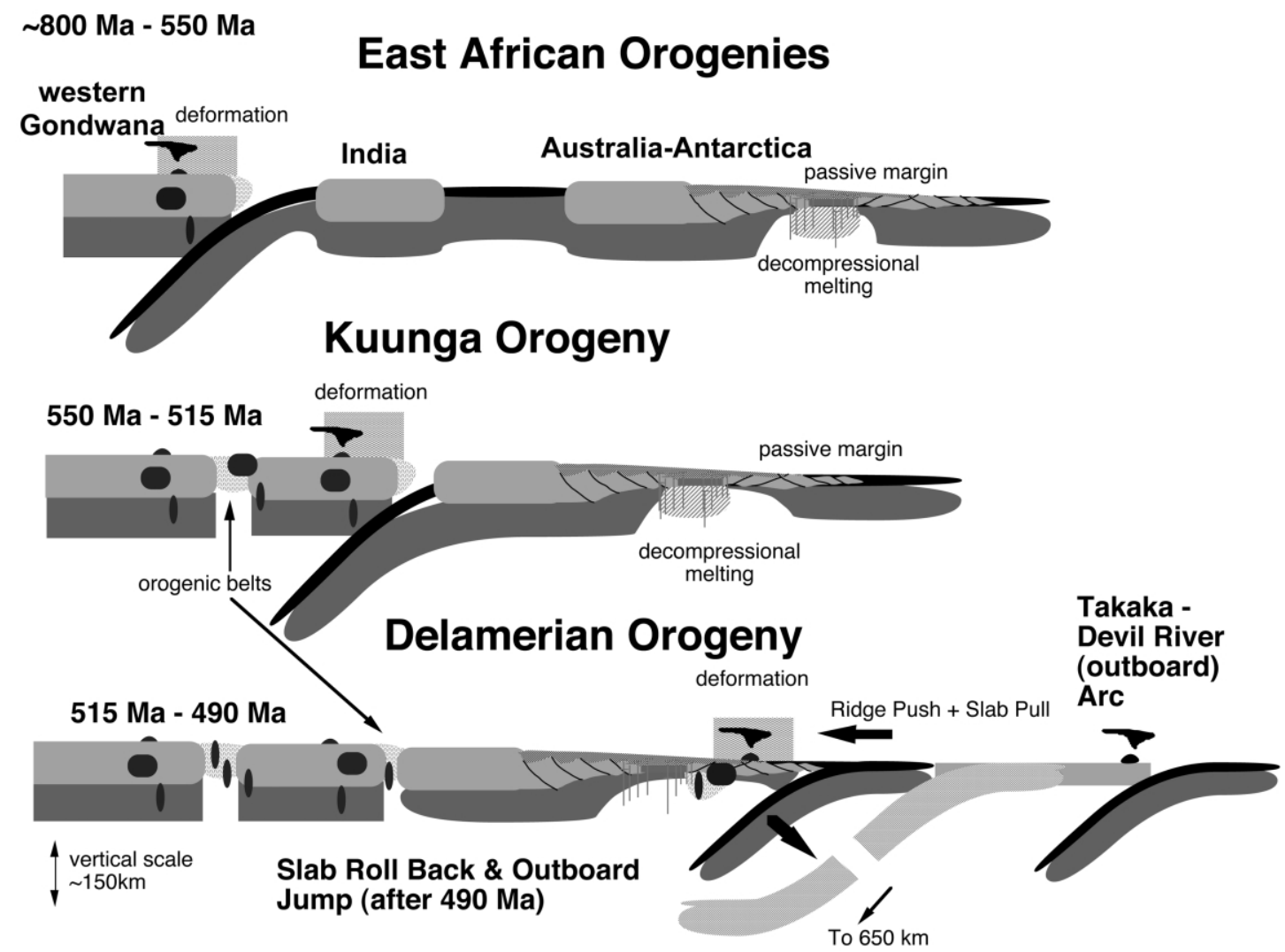

Figure 11. Cartoons (horizontal dimension not to scale) depicting the stages of Gondwanan lithospheric plate assembly and the transition of the eastern Australian-Antarctic trailing margin from passive extension to convergence and subduction during the Ross-Delamerian orogenies.

zircon age, indicating that this posttectonic igneous intrusion was emplaced into cool upper crust.

In South Australia there are no preserved proximal molasse deposits that might record this terminal Delamerian uplift, but in Tasmania such deposits are very widespread. These are the latest Cambrian and Early Ordovician Denison Group that comprise terrestrial and shallow marine, conglomerate-rich deposits and include the Jukes and Owen Conglomerates (Noll and Hall 2003). These are the products of apparently rapid sequential exhumation and erosion of the Cambrian and then Precambrian basement. Among these basement rocks are eclogites with $\mathrm{Rb}-\mathrm{Sr}$ mica ages of $485 \pm$ $4 \mathrm{Ma}$ (Raheim and Compston 1977). This age and a ${ }^{40} \mathrm{Ar} /{ }^{39} \mathrm{Ar}$ analysis of $489 \pm 9 \mathrm{Ma}$ on hornblende from the Mount Read Volcanics (Everard and Villa 1994) clearly indicate cooling due to exhumation and erosion occurred at the same time in Tasmania as in the Adelaide Fold Belt and in the Glenelg inlier (fig. 7).

As Turner et al. (1996) noted, the coincidence of the cooling ages from the fold belt with the ages of detrital micas deposited in flysch of mainly Ordovician age to the east in Victoria seems to suggest a causal link between Delamerian uplift and erosion and the termination of deformation. Our results strongly imply that the Delamerian Orogeny resulted from and was maintained by subduction. Evidence indicates that the fold belt reverted to extension $24 \mathrm{~m}$.yr. after the inception of convergent deformation. This is coupled with evidence that because the posttectonic uplift occurs after orogenic deformation has ceased, it is best interpreted as buoyancy-controlled exhumation. As discussed by Foden et al. $(2002 b)$, increased mafic magmatism and the shift of initial $\varepsilon \mathrm{Nd}$ values of postDelamerian A-type granites indicate that this was also associated with new mantle influx. The 24$\mathrm{m}$.yr. duration of convergent deformation following the apparent start of subduction is intriguing because it is the same time interval required for a newly foundering slab with a down-dip velocity of $2-3 \mathrm{~cm} / \mathrm{yr}$ to reach the $650-\mathrm{km}$ discontinuity. 
Newly established subducting slabs are demonstrated to inevitably lose most of their negative buoyancy at this middle mantle transition zone (Ranalli et al. 2000; Kincaid and Griffiths 2004). This results in slab rollback and immediate loss of transmission of plate-driving compressive stresses across the plate boundary to the continental margin and would thus have terminated the Delamerian Orogeny. This in turn also severs viscous coupling of upper and lower plates in the subduction zone, eliminating flexural drag and resulting in rapid upper plate exhumation. We suggest that the influx of hot asthenosphere mobilized by this rollback event would then have been the source of hightemperature posttectonic magmatism, including A- type granites in South Australia and the Mount Read Volcanics and Tyndall Group in Tasmania (fig. 11).

\section{A C K N O W L E D G M E N T S}

This article was significantly improved as a result of constructive comments made by F. Wombacher and an anonymous reviewer. The article was also improved as a result of discussions with and comments from numerous colleagues, including A. Collins, T. Crawford, N. Direen, P. Cawood, D. Glen, M. Fanning, W. Preiss, D. Taylor, and R. Caley. We also thank D. Bruce in the isotope laboratories at the University of Adelaide for his assistance.

\section{R E F E R E N C E S C I T E D}

Alias, G.; Sandiford, M.; Hand, M.; and Worley, B. 2002. The P-T record of synchronous magmatism, metamorphism and deformation at Petrel Cove, southern Adelaide Fold Belt. J. Metamorph. Geol. 20:351-363.

Armstrong, R. A.; De Wit, M.; Reid, D.; York, D.; and Zartmann, R. 1999. Cape Town's Table Mountain reveals rapid Pan-African uplift of its basement rocks. J. Afr. Earth Sci. 27:10-11.

Berry, R. F., and Crawford, A. R. 1988. The tectonic significance of Cambrian allochthonous mafic-ultramafic complexes in Tasmania. Aust. J. Earth Sci. 35: 523-533.

Boger, S. D., and Miller, J. M. 2004. Terminal suturing of Gondwana and the onset of the Ross-Delamerian Orogeny: the cause and effect of an Early Cambrian reconfiguration of plate motions. Earth Planet. Sci. Lett. 219:35-48.

Boger, S. D.; Wilson, C.; and Fanning, C. M. 2001. Early Palaeozoic tectonism within East Antarctic craton: the final suture between east and west Gondwana? Geology 29:463-466.

Burtt, A. C.; Abbot, P. J.; and Fanning, C. M. 2000. Definition of Teal Flat and Marne River Volcanics and associated shear zone. MESA J. 17:37-43.

Burtt, A. C., and Phillips, D. 2003. Ar/Ar dating of a pegmatite, Kinchina Quarry, Murray Bridge, South Australia. MESA J. 28:50-52.

Cas, R. A. F. 1983. Palaeogeographic and tectonic development of the Lachlan Fold Belt, southeastern Australia. Geol. Soc. Aust. Spec. Publ. 10.

Collins, A. 2003. Structure and age of the northern Leeuwin Complex, Western Australia. Aust. J. Earth Sci. 50:585-600.

Collins, A., and Pisarevsky, S. A. 2005. Amalgamating eastern Gondwana: the evolution of the CircumIndian Orogens. Earth Sci. Rev. 71:229-270.

Compston, W.; Crawford, A. R.; and Bofinger, V. M. 1966. A radiometric estimate of the duration of sedimen- tation in the Adelaide Geosyncline, South Australia. J. Geol. Soc. Aust. 13:229-276.

Coney, P. J.; Edwards, A.; Hine, R.; Morrison, F.; and Windrim, D. 1990. The regional tectonics of the Tasman orogenic system, eastern Australia. J. Struct. Geol. 12: 519-544.

Cooper, J. A.; Jenkins, R. J.; Compston, W.; and Williams, I. S. 1992. Ion-probe zircon dating of a mid-Early Cambrian tuff in South Australia. J. Geol. Soc. Lond. 149: 185-192.

Crawford, A. J., and Berry R. F. 1992. Tectonic implications of Late Proterozoic-Early Palaeozoic igneous rock associations in western Tasmania. Tectonophysics 214:37-56.

Dalziel, I. D. 1991. Pacific margins of Laurentia and East Antarctica-Australia as a conjugate rift pair: evidence and implications for an Eocambrian supercontinent. Geology 19:598-601.

Dougherty-Page, J. S., and Bartlett, J. M. 1999. New analytical procedures to increase the resolution of zircon geochronology by the evaporation technique. Chem. Geol. 153:227-240.

Dougherty-Page, J. S., and Foden, J. 1996. Pb-Pb zircon evaporation date for the Charleston Granite, South Australia: comparisons with other zircon geochronology techniques. Aust. J. Earth Sci. 43:133-137.

Drexel, J. F., and Preiss, W. 1995. The geology of South Australia. Vol. 2. The Phanerozoic. S. Aust. Geol. Surv. Bull. 54.

Dymoke, P., and Sandiford, M. 1992. Phase relationships in Buchan facies series pelitic assemblages: calculations with application to andalusite-staurolite parageneses in the Mount Lofty Ranges, South Australia. Contrib. Mineral. Petrol. 110:121-132.

Elburg, M. A.; Bons, P. D.; Dougherty-Page, J.; Janka, C. E.; Neumann, N.; and Schaefer, B. 2001. Age and metasomatic alteration of the Mt. Neill Granite at Nool- 
doonooldoona waterhole, Mt. Painter Inlier, South Australia. Aust. J. Earth Sci. 48:721-730.

Elburg, M. A.; Bons, P. D.; Foden, J.; and Brugger, J. 2003. A newly defined Late Ordovician magmatic-thermal event in the Mt. Painter Province, northern Flinders Ranges, South Australia. Aust. J. Earth Sci. 50:611631.

Encarnacion, J., and Grunow, A. 1996. Changing magmatic and tectonic styles along the paleo-Pacific margin of Gondwana and the onset of early Paleozoic magmatism in Antarctica. Tectonics 15:1325-1341.

Everard, J. L., and Villa, I. M. 1994. ${ }^{40} \mathrm{Ar}^{-39} \mathrm{Ar}$ dating of Mt. Read Volcanics, Tasmania. Aust. J. Earth Sci. 41: 265-272.

Fanning, C. M. 1990. Single grain dating of a granite sample from Cape Willoughby, Kangaroo Island. Prise Laboratories, Australian National University Progress Report 89-060. S. Aust. Dept. of Mines and Energy, Open File Envelope 8828:29-32.

Fergusson, C. L.; Cas, R.; and Stewart, I. R. 1989. Ordovician turbidites of the Hotham Group, eastern Victoria: sedimentation in deep-marine channel-levee complexes. Aust. J. Earth Sci. 36:1-12.

Fitzsimons, I. C. W. 2000. Grenville aged basement provinces in East Antarctica: evidence for three separate collisional orogens. Geology 28:879-882.

Fleming, P. D., and White, A. J. R. 1984. Relationships between deformation and partial melting in the Palmer migmatites, South Australia. Aust. J. Earth Sci. 31:352-360.

Flöttmann, T.; Haines, P.; Jago, J.; James, P.; Belperio, A.; and Gum, J. 1998. Formation and reactivation of the Cambrian Kanmantoo Trough, SE Australia: implications for Early Palaeozoic tectonics at eastern Gondwana's plate margin. J. Geol. Soc. Lond. 155:101-115.

Flöttmann, T.; James, P.; Rogers, J.; and Johnson, T. 1994. Early Palaeozoic foreland thrusting and basin reactivation at the palaeo-Pacific margin of the southeastern Australian Precambrian Craton: a reappraisal of the structural evolution of the southern Adelaide FoldThrust Belt. Tectonophysics 234:95-116.

Foden, J.; M. Sandiford; Dougherty-Page, J.; and Williams, I. 1999. Geochemistry and geochronology of the Rathjen Gneiss: implications for the early tectonic evolution of the Delamerian Orogen. Aust. J. Earth Sci. 46:377-389.

Foden, J.; Song, S.-H.; Turner, S.; Elburg, M.; Smith, P. B.; Van der Steldt, B.; and Van Penglis, D. 2002a. Geochemical evolution of lithospheric mantle beneath S.E. South Australia. Chem. Geol. 182:663-695.

Foden, J. D.; Elburg, M. A.; Turner, S. P.; Sandiford, M.; O'Callaghan, J.; and Mitchell, S. 2002b. Granite production in the Delamerian Orogen, South Australia. J. Geol. Soc. Lond. 159:1-19.

Foden, J. D.; Turner, S. P.; and Morrison, R. 1990. The tectonic implications of Delamerian magmatism in South Australia and western Victoria. Geol. Soc. Aust. Spec. Publ. 16:465-482.

Goodge, J. W. 1997. Latest Neoproterozoic basin inver- sion of the Beardmore Group, central Transantarctic Mountains, Antarctica. Tectonics 16:682-701.

Goodge, J. W., and Dallmeyer, R. D. 1992. ${ }^{40} \mathrm{Ar} /{ }^{39} \mathrm{Ar}$ mineral age constraints on the Precambrian tectonothermal evolution of high-grade basement rocks within the Ross Orogen, central Transantarctic Mountains. J. Geol. 100:91-106.

- 1996. Contrasting thermal evolution within the Ross Orogen, Antarctica: evidence from mineral ${ }^{40} \mathrm{Ar} /$ ${ }^{39}$ Ar ages. J. Geol. 104:435-458.

Goodge, J. W.; Hansen, V. L.; Peacock, S. M.; Smith, B. K.; and Walker, N. $1993 a$. Kinematic evolution of the Miller Range Shear Zone, central Transantarctic Mountains, Antarctica, and implications for Neoproterozoic to early Palaeozoic tectonics of the East Antarctic margin of Gondwana. Tectonics 12:1460-1478.

Goodge, J. W.; Hansen, V. L.; and Walker, N. 1993b. Neoproterozoic-Cambrian basement-involved orogenesis within the Antarctic margin of Gondwana. Geology 21:37-40.

Grunow, A.; Hanson, R.; and Wilson, T. 1996. Were aspects of Pan-African deformation linked to Iapetus opening? Geology 24:1063-1066.

Haines, P. W., and Flöttmann, T. 1998. The Delamerian Orogeny and potential foreland sedimentation: a review of age and stratigraphic constraints. Aust. J. Earth Sci. 45:559-570.

Haines, P. W.; Jago, J. B.; and Gum, J. 2001. Turbidite deposition in the Cambrian Kanmantoo Group, South Australia. Aust. J. Earth Sci. 48:465-478.

Hanchar, J. M., and Miller, C. F. 1993. Zircon zonation patterns as revealed by cathodoluminescence and backscattered electron images: implications for interpretation of complex crustal histories. Chem. Geol. 110:1-13.

Ireland, T.; Flöttmann, T.; Fanning, M.; Gibson, G.; and Preiss, W. V. 1998. Development of the Early Palaeozoic Pacific margin of Gondwana from detrital-zircon ages across the Delamerian Orogen. Geology 26:243246.

Ireland, T.; Morand, V. J.; and Gibson, G. 2002. Results from some recent SHRIMP U-Pb zircon dating of rocks from the Glenelg Zone of western Victoria. Geol. Surv. Vic. Tech. Rec. 2002/2, 23 p.

Jacobs, J.; Fanning, C. M.; Henjes-Kunst, F.; Olesch, M.; and Paech, H. 1998. Continuation of the Mozambique Belt into east Antarctica: Grenville-age metamorphism and polyphase Pan-African high-grade events in central Dronning Maud Land. J. Geol. 102:47-65.

Jenkins, R. J.; Cooper, J. C.; and Compston, W. 2002. Age and biostratigraphy of Early Cambrian tuffs from SE Australia and southern China. J. Geol. Soc. Lond. 159: 645-658.

Jenkins, R. J., and Sandiford, M. 1992. Observations on the tectonic evolution of the southern Adelaide Fold Belt. Tectonophysics 214:27-36.

Jung, S., and Mezger, K. 2001. Geochronology in migmatites: a Sm-Nd, U-Pb and Rb-Sr study from the Proterozoic Damara belt (Namibia): implications for poly- 
phase development of migmatites in high-grade terranes. J. Metamorph. Geol. 19:77-97.

Jung, S.; Mezger, K.; and Hoernes, S. 1998. Petrology and geochemistry of syn- to post-collisional metaluminous A-type granites: a major and trace element and $\mathrm{Nd}-\mathrm{Sr}-\mathrm{Pb}-\mathrm{O}$-isotope study from the Proterozoic Damara Belt, Namibia. Lithos 45:147-175.

2001. Trace element and isotopic ( $\mathrm{Sr}, \mathrm{Nd}, \mathrm{Pb}, \mathrm{O})$ arguments for a mid-crustal origin of Pan-African garnet-bearing S-type granites from the Damara Orogen (Namibia). Precambrian Res. 110:325-355.

Kemp, A. I. S. 2003. Plutonic boninite-like rocks in anatectic setting: tectonic implications for the Delamerian Orogen in southeastern Australia. Geology 31: 371-374.

Kincaid, C., and Griffiths, R. W. 2004. Variability in flow and temperatures within mantle subduction zones. Geochem. Geophys. Geosyst., vol. 5, doi: 10.1029/ 2003GC000666.

Kober, B. 1986. Whole grain evaporation for ${ }^{207} \mathrm{~Pb} /{ }^{206} \mathrm{~Pb}$ age investigations using a double-filament ion source. Contrib. Mineral. Petrol. 93:482-490.

Ludwig, K. R. 1999. Using ISOPLOT/Ex, version 2.01: a geochronological toolkit for Microsoft Excel. Berkeley Geochronol. Center Spec. Publ. 1a, 47 p.

Mancktelow, N. S. 1990. The structure of the southern Adelaide Fold Belt, South Australia. In Jago, J. B., and Moore, P. J., eds. The evolution of a Late PrecambrianEarly Palaeozoic Rift Complex: the Adelaide Geosyncline. Geol. Soc. Aust. Spec. Publ. 16:483-495.

Meert, J. G. 2003. A synopsis of events related to the assembly of eastern Gondwana. Tectonophysics 362: $1-40$.

Meffre, S.; Direen, N. G.; Crawford, A. J.; and Kamenetsky, V. 2004. Mafic volcanic rocks on King Island, Tasmania: evidence for 579 Ma break-up in east Gondwana. Precambrian Res. 135:177-191.

Mezger, K., and Cosca, M. A. 1999. The thermal history of the Eastern Ghats (India) as revealed by U-Pb and ${ }^{40} \mathrm{Ar} /{ }^{39} \mathrm{Ar}$ dating of metamorphic and magmatic minerals: implications for the SWEAT correlation. Precambrian Res. 94:251-271.

Millar, I. A., and Storey, B. C. 1995. Early Palaeozoic rather than Neoproterozoic volcanism and rifting within the Transantarctic Mountains. J. Geol. Soc. Lond. 152:417-460.

Milnes, A. R.; Compston, W.; and Daily, B. 1977. Pre- to syn-tectonic emplacement of early Palaeozoic granites in southeastern South Australia. J. Geol. Soc. Aust. 24:87-106.

Morrison, R. S., and Foden, J. 1990. A zoned pluton in the Peake and Denison Ranges, South Australia: implications for mid-Cambrian magmatism in the Adelaide Geosyncline. Geol. Soc. Aust. Spec. Publ. 13: 450-464.

Münker, C. 2000. The isotope and trace element budget of the Cambrian Devil River arc system, New Zealand: identification of four source components. J. Petrol. 41:759-788.

Münker, C., and Cooper, R. A. 1995. The island arc set- ting of a New Zealand Cambrian volcano-sedimentary sequence: implications for the evolution of the SW Pacific Gondwana fragments. J. Geol. 103:687-700.

Münker, C., and Crawford, A. J. 2000. Cambrian arc evolution along the SE Gondwana active margin: a synthesis from Tasmania-New Zealand-Australia-Antarctica correlations. Tectonics 19:415-432.

Myrow, P. M.; Pope, M. C.; Goodge, J. W.; Fischer, W.; and Palmer, A. R. 2002. Depositional history of preDevonian strata and timing of Ross orogenic tectonism in the central Transantarctic Mountains, Antarctica. Geol. Soc. Am. Bull. 114:1070-1088.

Noll, C. A., and Hall, M. 2003. Stratigraphic architecture and depositional setting of the coarse-grained Upper Cambrian Owen Conglomerate, West Coast range, western Tasmania. Aust. J. Earth Sci. 50:835-852.

Offler, R., and Fleming, P. 1968. A synthesis of folding and metamorphism in the Mt. Lofty Ranges, South Australia. J. Geol. Soc. Aust. 15:245-266.

Pankhurst, R. J.; Storey, B. C.; Millar, I. L.; Macdonald, D.; and Vennum, W. R. 1988. Cambrian-Ordovician magmatism in the Thiel Mountains, Transantarctic Mountains, and implications for the Beardmore Orogeny. Geology 16:246-249.

Paul, E.; Flöttmann, T.; and Sandiford, M. 1999. Structural geometry and controls on basement-involved deformation in the northern Flinders Ranges, Adelaide Fold Belt, South Australia. Aust. J. Earth Sci. 46:343-354.

Perkins, C., and Walsh, J. L. 1993. Geochronology of the Mt. Read Volcanics, Tasmania, Australia. Econ. Geol. 88:1176-1197.

Pinna, P.; Jourde, G.; Calvez, J. Y.; Mroz, J. P.; and Marques, J. M. 1993. The Mozambique Belt in northern Mozambique: Neoproterozoic (1100-850 Ma) crustal growth and tectonogenesis, and superimposed PanAfrican (800-550 Ma) tectonism. Precambrian Res. 62: $1-5$.

Powell, C. M.; Preiss, W.; Gatehouse, C.; Krapez, B.; and Li, Z. 1994. South Australian record of a Rodinian epicontinental basin and its mid-Neoproterozoic break-up (700 Ma) to form the Palaeo-Pacific ocean. Tectonophysics 237:113-140.

Preiss, W. V. 1987. The Adelaide Geosyncline: Late Proterozoic stratigraphy, sedimentation, palaeontology and tectonics. Geol. Surv. S. Aust. Bull. 53:34-41.

Raheim, A., and Compston, W. 1977. Correlation between metamorphic events and $\mathrm{Rb}-\mathrm{Sr}$ ages in metasediments and eclogite from western Tasmania. Lithos 10:271-289.

Ranalli, G.; Pellegrini, R.; and D'Offizi, S. 2000. Time dependence of negative buoyancy and the subduction of continental lithosphere. J. Geodyn. 30:539-555.

Rickers, K.; Mezger, K.; and Raith, M. M. 2001. Evolution of the continental crust in the Proterozoic Eastern Ghats Belt, India and new constraints for Rodinia reconstruction: implications from $\mathrm{Sm}-\mathrm{Nd}, \mathrm{Rb}-\mathrm{Sr}$ and $\mathrm{Pb}$ $\mathrm{Pb}$ isotopes. Precambrian Res. 112:183-210.

Rowell, A. J.; Rees, M. N.; Duebendorfer, E. M.; Wallin, E. T.; Van-Schmus, W. R.; and Smith, E. I. 1993. An active Neoproterozoic margin: evidence from the 
Skelton Glacier area, Transantarctic Mountains. J. Geol. Soc. Lond. 150:677-687.

Sandiford, M.; Foden, J.; Zhou, S.; and Turner, S. 1992. Granite genesis and the mechanics of convergent orogenic belts with application to the southern Adelaide Fold Belt. Trans. R. Soc. Edinb. Earth Sci. 83:83-93.

Stacey, J. S., and Kramers, J. D. 1975. Approximation of terrestrial lead isotope evolution by a two-stage model. Earth Planet. Sci. Lett. 26:207-221.

Stump, E. 1995. The Ross Orogen of the Transantarctic Mountains. New York, Cambridge University Press, $284 \mathrm{p}$.

Turner, N. J.; Black, L. P.; and Kamperman, M. 1998. Proterozoic and Cambrian orogenies in Tasmania. Aust. J. Earth Sci. 45:789-806.

Turner, S., and Foden J. D. 1996. Petrogenesis of lateDelamerian A-type granites and granophyre, South Australia: magma mingling in the Mannum granite, South Australia. Mineral. Petrol. 56:147-169.
Turner, S. P. 1996. Petrogenesis of the late-Delamerian gabbroic complex at Black Hill, South Australia: implications for convective thinning of the lithospheric mantle. Mineral. Petrol. 56:51-89.

Turner, S. P.; Foden, J. D.; and Morrison, R. S. 1992. Derivation of an A-type magma by fractionation of basaltic magma: an example from the Padthaway Ridge, South Australia. Lithos 28:151-179.

Turner, S. P.; Kelley, S. P.; VandenBerg, A. H. M.; Foden, J. D.; Sandiford, M.; and Flöttmann, T. 1996. Source of the Lachlan fold belt flysch linked to convective removal of the lithospheric mantle and rapid exhumation of the Delamerian-Ross fold belt. Geology 24: 941-944.

Wombacher, F., and Münker, C. 2000. Pb, Nd, and $\mathrm{Sr}$ isotopes and REE systematics of Cambrian sediments from New Zealand: implications for the reconstruction of the Early Palaeozoic Gondwana Margin along Australia and Antarctica. J. Geol. 108:663-686. 
Copyright of Journal of Geology is the property of University of Chicago Press and its content may not be copied or emailed to multiple sites or posted to a listserv without the copyright holder's express written permission. However, users may print, download, or email articles for individual use. 